\title{
Review \\ Multiplicity of Glycosphingolipid-Enriched Microdomain-Driven Immune Signaling
}

\author{
Noriko Yokoyama ${ }^{1,+}+$ D, Kei Hanafusa ${ }^{1,+}{ }^{,}$, Tomomi Hotta ${ }^{1}$, Eriko Oshima ${ }^{1}$, Kazuhisa Iwabuchi ${ }^{1,2,3}{ }^{1 D}$ \\ and Hitoshi Nakayama $1,2,3, *$
}

1 Institute for Environmental and Gender-Specific Medicine, Juntendo University, Graduate School of Medicine, Urayasu, Chiba 279-0021, Japan; n-yokoyama@juntendo.ac.jp (N.Y.); k.hanafusa.nt@juntendo.ac.jp (K.H.); t-hotta@juntendo.ac.jp (T.H.); e.osuka.wc@juntendo.ac.jp (E.O.); iwabuchi@juntendo.ac.jp (K.I.)

2 Laboratory of Biochemistry, Juntendo University Faculty of Health Care and Nursing, Urayasu, Chiba 279-0023, Japan

3 Infection Control Nursing, Juntendo University Graduate School of Health Care and Nursing, Urayasu, Chiba 279-0023, Japan

* Correspondence: nhitoshi@juntendo.ac.jp; Tel.: +81-47-353-3171; Fax: +81-47-353-3178

+ These authors contributed equally to this work.

check for updates

Citation: Yokoyama, N.; Hanafusa, K.; Hotta, T.; Oshima, E.; Iwabuchi, K.; Nakayama, H. Multiplicity of Glycosphingolipid-Enriched Microdomain-Driven Immune Signaling. Int. J. Mol. Sci. 2021, 22, 9565. https://doi.org/10.3390/ ijms22179565

Academic Editor:

Jean-Pierre Jaffrézou

Received: 30 July 2021

Accepted: 1 September 2021

Published: 3 September 2021

Publisher's Note: MDPI stays neutral with regard to jurisdictional claims in published maps and institutional affiliations.

Copyright: (c) 2021 by the authors. Licensee MDPI, Basel, Switzerland. This article is an open access article distributed under the terms and conditions of the Creative Commons Attribution (CC BY) license (https:// creativecommons.org/licenses/by/ $4.0 /)$.

\begin{abstract}
Glycosphingolipids (GSLs), together with cholesterol, sphingomyelin (SM), and glycosylphosphatidylinositol (GPI)-anchored and membrane-associated signal transduction molecules, form GSL-enriched microdomains. These specialized microdomains interact in a cis manner with various immune receptors, affecting immune receptor-mediated signaling. This, in turn, results in the regulation of a broad range of immunological functions, including phagocytosis, cytokine production, antigen presentation and apoptosis. In addition, GSLs alone can regulate immunological functions by acting as ligands for immune receptors, and exogenous GSLs can alter the organization of microdomains and microdomain-associated signaling. Many pathogens, including viruses, bacteria and fungi, enter host cells by binding to GSL-enriched microdomains. Intracellular pathogens survive inside phagocytes by manipulating intracellular microdomain-driven signaling and/or sphingolipid metabolism pathways. This review describes the mechanisms by which GSL-enriched microdomains regulate immune signaling.
\end{abstract}

Keywords: glycosphingolipids; microdomain; immune signaling

\section{Introduction}

Membrane microdomains, also called lipid rafts, consist of glycosphingolipids (GSLs), cholesterol, sphingomyelin (SM), glycosylphosphatidylinositol (GPI)-anchored proteins and membrane-associated signal transduction molecules [1,2]. GSLs, a predominant component of microdomains, are characterized structurally by their hydrophobic ceramide and hydrophilic glycan moieties. The ceramide moiety contains fatty acid chains that vary widely in length [3]. More than 400 types of GSLs have been identified based on differences in their glycan structures [4]. Cell surface receptors bind ligands expressed on other cells (in trans) to communicate with neighboring cells, whereas a large number of cell surface receptors interact with ligands expressed on the same cell (in cis) [5]. The hydrophobic ceramide moiety enables GSLs to interact with the steroid ring system of cholesterol via van der Waals forces and hydrogen bonds [6,7]. In addition, the hydrophilic glycan moieties of GSLs interact in cis with each other, promoting the lateral interaction of GSLs with other components of cellular membranes. These interactions result in the phase separation of GSL-enriched membrane microdomains. GSL-enriched microdomains in the outer surfaces of membranes are able to associate with membrane proteins and lipid-anchored signal transduction molecules, which are localized in the inner surfaces of membranes [8-10]. These supramolecular complexes provide signaling platforms for cellular functions. The 
types of GSLs and their metabolism are not only cell type specific but also depend on whether the cells are proliferating or differentiating $[4,11]$. GSL-enriched microdomains are therefore thought to be involved in a large number of biological functions, including immunological functions (Figures 1 and 2). This review describes the mechanisms by which GSL-enriched microdomains modulate receptor functions and signal transductions in immune signaling, focusing generally on findings in our laboratory.

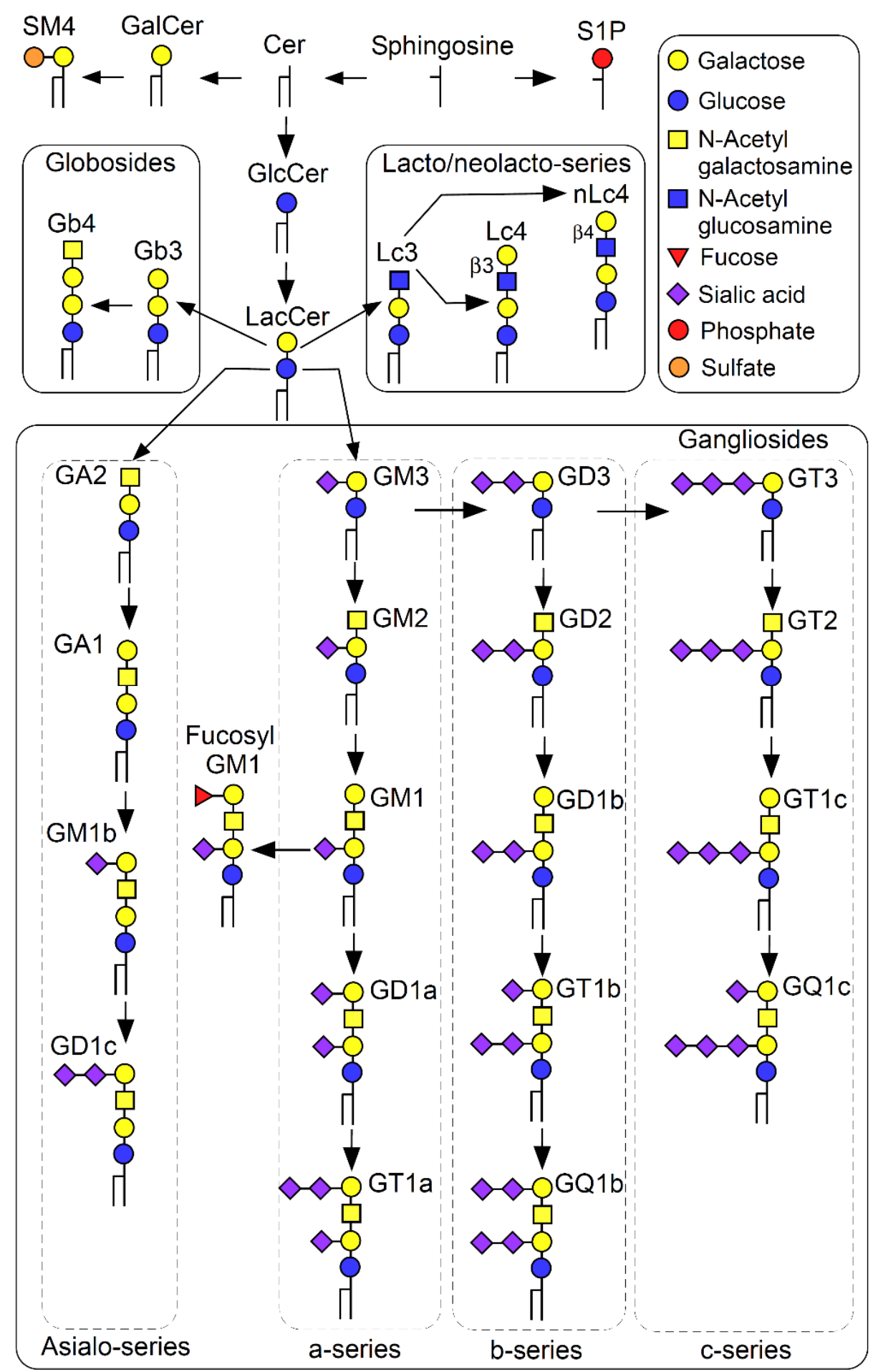

Figure 1. Schematic pathway of GSL biosynthesis. GSLs and the related molecules referred to in this review are shown. 
A

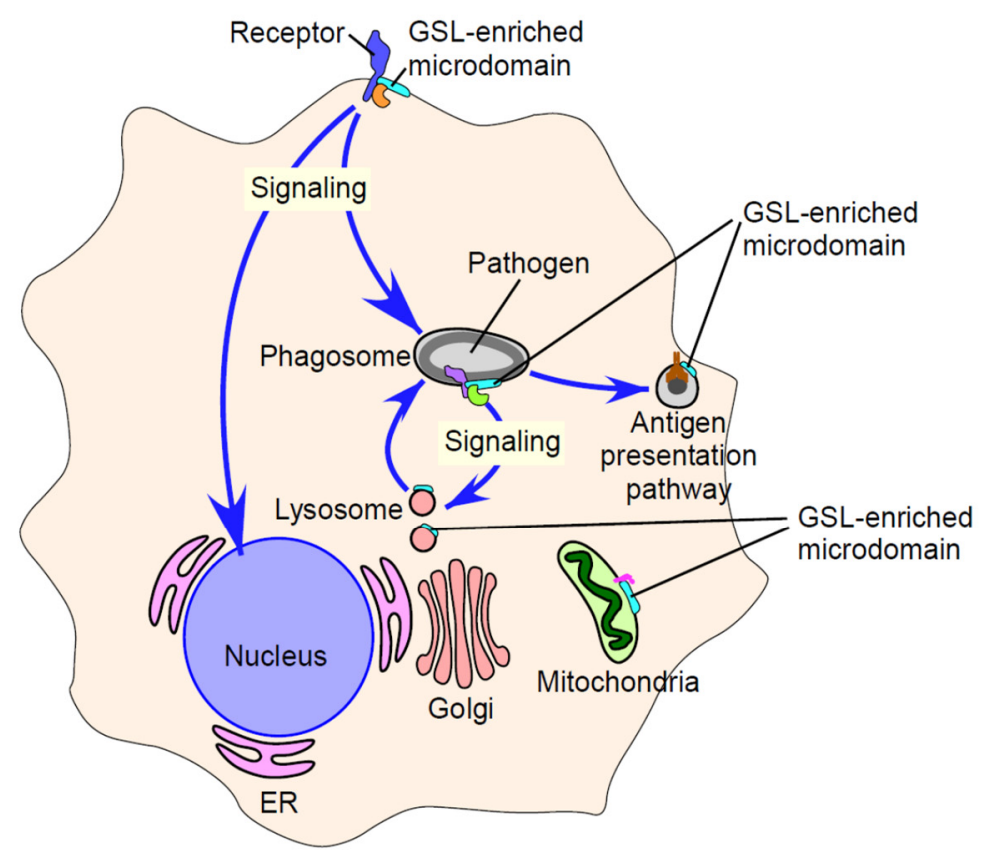

B
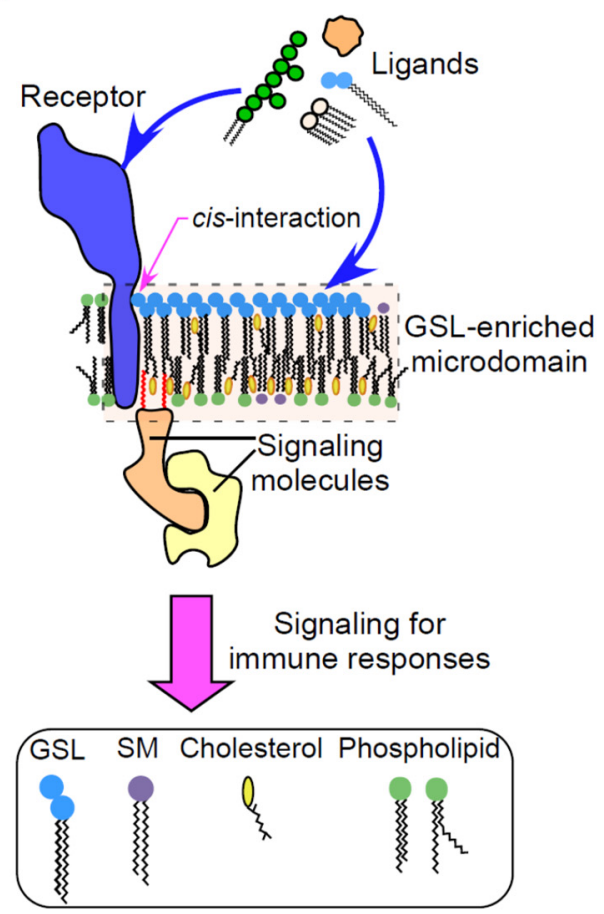

Figure 2. Multiplicity of GSL-enriched microdomain-driven immune signaling. (A) Schematic image showing multiplicity of GSL-enriched microdomain-driven signaling in immune cells. In both innate and adaptive immunity, GSL-enriched microdomains affect immune signaling by themselves or by cis-interaction with various immune receptors. This results in various immune responses, such as cytokine production, phagocytosis/phagosome maturation, antigen presentation and apoptosis. GSL-enriched microdomains are present not only in plasma membranes but also in membranes of intracellular organelles, such as lysosomes and phagosomes. LacCer forms membrane microdomains on intracellular granules, including lysosomes, in human neutrophils, and these LacCer-enriched microdomains on phagosomes act as a platform of intracellular signaling required for phagosome maturation (fusion of lysosomes to pathogen-containing phagosomes). GD3 forms membrane microdomains on mitochondria-associated membranes (MAMs) and contributes to autophagosome assembly. ER, endoplasmic reticulum. Golgi, Golgi apparatus. (B) Schematic image showing cis-interactions between GSL-enriched microdomains and immune receptors. The transfer of signals induced by ligand binding into cells involves the direct binding of these ligands to GSL-enriched microdomains in plasma membranes, followed by the transduction of the signals through membrane-associated signal transduction molecules. In addition, signaling molecule-associated GSL-enriched microdomains interact in cis with various receptor proteins, leading to a variety of immune responses. Thus, GSL-enriched microdomains provide signaling platforms for ligand binding to the plasma membranes of immune cells. Intracellular GSLenriched microdomains may provide platforms for cross-talk among several types of proteins, such as membrane-associated and signaling proteins and sphingolipid metabolites.

\section{Physicochemical Properties of GSL-Enriched Microdomains}

A biological membrane consisting of a lipid bilayer is often compared to a sea of phospholipids and cholesterol with floating sphingolipids and membrane proteins. Depending on their physicochemical properties, membrane components are distributed in a non-homogeneous manner throughout the cell membrane, leading to the formation of membrane microdomains that differ in molecular composition. These microdomains form supramolecular structures, which are stabilized by lateral intermolecular interactions. The properties of membrane components provide physical boundaries between the outside and the inside of cells. GSLs are specifically expressed in the outer layer of cell membranes [2]. GSLs can form clusters on cell membranes by lateral interactions based on their physicochemical properties, including hydrogen bonds from hydroxyl groups, the acetamide structure of the ceramide moiety and van der Waals interactions between hydrocarbon chains [11]. The physicochemical properties of GSLs suggest that they form defined clus- 
ters and that certain proteins cannot undergo free and continuous lateral diffusion in the membrane but rather are transiently confined to microdomains $[4,12,13]$. Because there are many difficulties evaluating GSL-enriched membrane microdomains in their original state, the actual state of GSL-enriched membrane microdomains remains unclear. Techniques to determine the structural and molecular arrangements of GSL-enriched membrane microdomains include single-molecule fluorescence tracking and electron microscopy. Although several GSL analogues have been generated by attaching a fluorescent label to the carbohydrate or lipid portion, it is unclear whether these analogues behave identically to natural unlabeled molecules [14]. Recently, hydrophilic fluorophore-conjugated analogues of gangliosides (sialylated GSLs), such as GM3, GM2 and GM1, were shown to be useful for the assessment of these microdomains, because these analogues retain binding specificity to their ligands $[15,16]$. Fluorescent-labeled SM analogues have been developed, consisting of hydrophilic fluorophores conjugated to the choline headgroup of SM via a hydrophilic nonaethylene glycol linker, which retain their positive charge [17]. These analogues have been shown to behave similarly to native SM in artificial liquid ordered (Lo)-disordered (Ld) phase-separated giant unilamellar vesicles (GUVs) and detergent-resistant membranes (DRMs) from cells.

The sizes of lipid microdomains range from 10 to $200 \mathrm{~nm}$ in diameter [1]. In comparison, GSL-enriched microdomains, consisting of GSLs that assemble laterally due to their physicochemical properties, have been reported to be $50-100 \mathrm{~nm}$ in diameter $[18,19]$. Immunoelectron microscopy showed that the neutral GSL lactosylceramide (LacCer, CDw17) forms microdomains with a diameter of about $43 \mathrm{~nm}$ in the plasma membranes of resting human neutrophils [18]. The phagocytosis of microorganisms by neutrophils induced the formation of larger LacCer-enriched microdomains, about $60 \mathrm{~nm}$ in diameter [20], on phagosomal membranes, suggesting that the reorganized LacCer-enriched microdomains provide platforms for transducing phagosome-lysosome fusion through molecular interactions, such as protein-lipid interactions. Single-molecule imaging with fluorescently labeled GPI-anchored proteins biophysically determined that these microdomains are dynamic domains with a diameter of about $10 \mathrm{~nm}$ [21,22]. Thus, the sizes of microdomains depend on the types of observed molecules. These differences may depend not only on the experimental methods used for observation but also on the physical properties of the observed molecules. Unlike GPI-anchored proteins, carbohydrates in GSLs are almost the same as ceramide, and the melting point of neutral GSLs is above $65^{\circ} \mathrm{C}$ [23]. Therefore, the lateral interactions among GSLs appear to be very strong, enabling GSLs to pack together in plasma membranes. Acidic GSLs, such as gangliosides, have a much lower melting point than neutral GSLs. Moreover, the phase transition temperature of reconstructed ganglioside-enriched microdomains is around $40{ }^{\circ} \mathrm{C}$, indicating that these microdomains can exist as distinct domains on phospholipid temperatures at body temperature [24]. Indeed, GSLs with different types of glycan structures have been shown to constitute distinct microdomains on the same cells and to have distinct functions [19,25]. Moreover, the interdigitation of long acyl chain SM in the outer leaflet and phosphatidylserine (PS) in the inner leaflet of the plasma membrane has been reported [26,27]. Interestingly, GM1 containing $\mathrm{C} 16: 0$ but not $\mathrm{C} 16: 1$ acyl chains was reported to form nanoclusters without the ligand cholera toxin B subunit (CTxB) [28]. Moreover, CTxB was found to induce the co-clustering of GM1 containing C16:0 with the GPI-anchored protein CD59, whereas such co-clustering did not occur with GM1 containing C16:1. These results suggest that the acyl chain structures of the ceramide moiety in GSLs also affect the properties of microdomains.

\section{GSL-Enriched Microdomains as Regulators of Immune Receptor Signaling}

Following the binding of ligands to membrane receptors, the receptors undergo conformational changes, transferring signaling into the cells. During this process, GSL-enriched microdomains interact with various receptor proteins in cis, inducing physiological and immune system activities (Figure 1). This section describes the mechanisms by which receptors are regulated by GSL-enriched microdomains. The best known mechanisms 
are ganglioside-receptor protein interactions. Lateral interactions between GM3-enriched microdomains and insulin receptors (IRs) through a basic lysine residue (K944) lead to the inhibition of insulin-induced signaling in adipocytes [29]. Therefore, an increase in GM3 expression in cells may result in insulin resistance. Moreover, in the absence of epidermal growth factor (EGF), autophosphorylation of the EGF receptor (EGFR) is suppressed by its cis-interaction with GM3 through a lysine residue (K642) [30]. Adipogenic stimulation of adipose progenitor cells induces the accumulation of GM3- and caveolin 1-positive microdomains at the base of the primary cilia [31]. This accumulation, however, is reduced by the loss of trichoplein, resulting in the inhibition of IR/insulin-like growth factor-1 (IGF-1) receptor (IGF1R)-Akt signaling and protection from obesity and metabolic syndrome. Molecular dynamics (MD) simulations have shown that GM3 binds to the extracellular domain of the glucagon receptor, a class B1 G-protein-coupled receptor (GPCR), and modulates the dynamics of the extracellular domain, suggesting that GM3 plays a role in regulating the insulin/glucagon signaling ratio [32]. Thus, GM3-enriched microdomains appear to be critical for metabolic regulation. An evaluation of these GM3-receptor interactions suggested that an increase in GM3 content involved the glucose-induced inhibition of IGF1R-Rac1 signaling, affecting keratinocyte motility [33]. This finding suggests possible therapeutic approaches for treating wounds in patients with diabetes.

In addition to GM3, GM1, which is most abundant in neurons, interacts in cis with neurotrophin receptors [34] and modulates laminin-1-induced neurite outgrowth via TrkA and $\beta_{1}$ integrin [35]. A study using tritium-labeled GM1 photoactivable derivatives suggested mechanisms by which GM1 interact in cis with receptors, such as TrkA [36]. The formation of the GM1-TrkA complex through those oligosaccharide interactions was found to promote neuroblastoma cell differentiation. In addition, GM1 was found to interact in cis with the GPCR serotonin-1A receptor [37]. Most (>90\%) gangliosides in adult mammalian brains are composed of GM1, GD1a, GD1b and GT1b, which differ in the number and position of sialic acids linked to a common tetrasaccharide core [38]. GT1b is particularly recognized by botulinum neurotoxin type B (BoNT/B) [39], with a GT1b-synaptotagmin (SYT) cis-interactive molecular complex constituting a high-affinity BoNT/B receptor [40]. Similar to the cis-interactions of GM3 with IR and EGFR, a lysine residue (K52) on the SYT-juxtamembrane was found to be critical for the SYT-GT1b cis-interactions required for BoNT/B binding.

GSL-enriched microdomains are also associated with receptor-mediated immune signaling (Table 1). In innate immune responses, various pattern-recognition receptors (PRRs), including TLRs and integrins, are crucial for the detection of invading pathogens. Immune signaling is subsequently activated in neutrophils, macrophages and dendritic cells, resulting in pathogen removal. This elimination pathway is initiated by the binding of pathogen-derived molecules, called pathogen-associated molecular patterns (PAMPs), to PRRs expressed on phagocytes, leading to the formation of nascent phagosomes containing pathogens and their subsequent fusion to lysosomes. In particular, macrophages and dendritic cells are responsible for the antigen presentation of pathogen-derived molecules via major histocompatibility complex (MHC)-mediated pathways, resulting in the induction of acquired immune responses. TLRs are the best-characterized germline-encoded PRR proteins, and they transmit signals through several adaptor molecules [41]. TLR4 was the first member of the TLR family to be identified functionally [42]. TLR4 binds to lipopolysaccharide (LPS) with the support of GPI-anchored protein CD14, suggesting that TLR4 is activated at the sites of membrane microdomains [43]. The interaction of receptor molecules with membrane microdomains containing GM1 during LPS-induced cellular activation [44] was evaluated by fluorescence resonance energy transfer (FRET), which showed that TLR4 is associated with GM1-positive membrane microdomains after stimulation with LPS. A cholesterol-binding motif of TLR4 is regarded as critical for its translocation into membrane microdomains [45], suggesting that sphingolipids may not be involved in TLR4 signaling [46]. Recent atomistic molecular dynamics (MD) simulations regarding the TLR4 dimer complex showed that glucosylceramide (GlcCer) enhanced 
electrostatic interactions of the TLR4 extracellular domain with membranes [47]. This result suggests that the effects of GlcCer on LPS/TLR4 orientation affects LPS/TLR4 signaling through MyD88 adapter-like (Mal), also termed TIRAP. Thus, additional investigations are required to elucidate the mechanisms underlying the cis-interactions of TLR4 with membrane microdomain components. Cross-talk between neurotrophic receptors and TLR4 is also thought to be involved in neuroprotection mechanisms [48]. An extract from inflamed rabbit skin inoculated with vaccinia virus (Neurotropin ${ }^{\circledR}, \mathrm{NTP}$ ) was shown to control nerve growth factor (NGF) receptor TrkA-mediated TLR4-associated signaling through clusters of newly formed membrane microdomains in PC12 cells. GSL-enriched microdomains involve not only TLR4-mediated immune functions but also functions mediated by other members of the TLR family. For example, the binding of bacterial flagellin to asialoGM1 and TLR5 expressed on human lung epithelial cells was found to induce the autocrine release of ATP [49]. This released ATP binds to and activates ATP receptors in plasma membranes, leading to $\mathrm{Ca}^{2+}$ mobilization and Erk1/2 phosphorylation. GD1a on human monocytes binds to the subunit of type IIb Escherichia coli enterotoxin, promoting its interaction with the TLR2/TLR1 signaling complex and activating NF-KB [50].

Table 1. GSLs and receptor-mediated immune signaling.

\begin{tabular}{|c|c|c|c|c|}
\hline GSLs & Co-Receptors & Cell Type & Immune Signaling & Ref. No. \\
\hline GlcCer & TLR4 & Macrophages & $\begin{array}{l}\text { Impact on LPS/TLR4 orientation and } \\
\text { Mal-associated signaling }\end{array}$ & [47] \\
\hline GA1 & TLR5 & $\begin{array}{l}\text { Lung epithelial cells } \\
\text { NCIH292 }\end{array}$ & $\begin{array}{l}\text { Flagellin-mediated autocrine release } \\
\text { of ATP }\end{array}$ & [49] \\
\hline GD1a & TLR2/TLR1 & Monocytes & LT-IIb-B ${ }_{5}$-mediated NFkB activation & [50] \\
\hline LacCer & $\mathrm{CD} 11 \mathrm{~b} / \mathrm{CD} 18$ & Neutrophils & $\begin{array}{l}\text { Lyn and Akt activations, and the } \\
\text { resulting phagocytosis of zymosan } \\
\text { and mycobacteria }\end{array}$ & {$[20,51]$} \\
\hline Gb3Cer & CD59 & $\begin{array}{l}\text { Lung epithelial cells } \\
\text { H1299 }\end{array}$ & $\begin{array}{l}\text { PIP3 and flotillin-associated uptake of } \\
\text { P. aeruginosa }\end{array}$ & {$[52]$} \\
\hline $\begin{array}{l}\text { Neolacto-series } \\
\quad \text { GSLs }\end{array}$ & MHC class I & HAP1 cells & $\begin{array}{l}\text { Interference of the accessibility of } \\
\text { MHC class I molecules for immune } \\
\text { cell receptors and the resulting } \\
\text { suppression of } C D 8^{+} \text {T-cell activation }\end{array}$ & [53] \\
\hline GM1, GM3 & CD4, LFA-1 & T-cell line & $\begin{array}{c}\text { PI3K and p56lck-associated T-cell } \\
\text { responses }\end{array}$ & [54] \\
\hline $\begin{array}{c}\text { a-Series } \\
\text { gangliosides }\end{array}$ & CD4, TCR & $\mathrm{T}$ cells & Helper T-cell activation & [55] \\
\hline $\begin{array}{l}\text { Asialo-series } \\
\text { gangliosides }\end{array}$ & CD8, TCR & T cells & Killer T-cell activation & [55] \\
\hline GM1 & $\operatorname{IgM-BCR}$ & Immature B cells & $\begin{array}{l}\text { Removal of autoreactive immature B } \\
\text { cells (apoptosis) }\end{array}$ & [56] \\
\hline GM3 & CD95/Fas & T cells & $\begin{array}{l}\text { Formation of death-inducing signaling } \\
\text { complex upon CD95/Fas engagement } \\
\text { (apoptosis) }\end{array}$ & [57] \\
\hline
\end{tabular}

\section{GSL-Enriched Microdomains in Immune Functions}

Several properties of neutrophils, including adhesion, migration and phagocytosis, are modulated by the CD11b/CD18 integrin, also called Mac-1, CR3 or $\alpha_{M} \beta_{2}$ integrin [58]. Despite CD11b/CD18 cytoplasmic regions lacking catalytic activity, CD11b/CD18 can transduce signals inside the cells [59]. These results suggest that CD11b/CD18-mediated outside-in signaling requires partner molecules as a signaling platform. Microdomains enriched in the neutral GSL LacCer can not only bind microbial ligands but can act as a 
signaling platform. That is, LacCer-enriched microdomains are able to act as a PRR for pathogens. Indeed, LacCer was found to bind to various pathogens and their PAMPs, including Candida albicans-derived $\beta$-glucan (CSBG) and mycobacterial lipoarabinomannan (LAM) [20,60], and to form membrane microdomains coupled to various signaling molecules, including the Src family kinase Lyn, through their very long C24 fatty acid chains, transducing ligand-binding signals to the inside of the cells [18]. In addition, Lyncoupled LacCer-enriched microdomains serve as a platform for CD11b/CD18-dependent outside-in and phagocytic signaling in human neutrophils [20,51,61]. LacCer-enriched microdomains are likely to interact in cis with the extracellular juxtamembrane region of CD18 [51]. In lung epithelial cells, the interaction of the Pseudomonas aeruginosa-derived virulence factor LecA with globotriaosylceramide (Gb3Cer) in the outer leaflet of plasma membranes was found to induce the formation of membrane domains enriched in saturated long fatty acyl chain-containing Gb3Cer species, the GPI-anchored protein CD59, phosphatidylinositol $(3,4,5)$-trisphosphate (PIP3) and flotillin, thereby promoting the efficient uptake of $P$. aeruginosa [52]. Mechanisms were suggested by which Gb3Cer and its associated molecules mediate signal transduction from extracellular to intracellular sites through transbilayer coupling. Thus, by providing a signaling platform, several types of GSL-enriched microdomains can regulate the function of receptors that lack catalytic moieties, such as CD11b/CD18. Moreover, the structures of GSLs, especially their fatty acid chains, may be a key component of GSL-enriched microdomains that act as signaling platforms.

GSLs may also be involved in MHC-mediated antigen presentation pathways. For example, MHC class II molecules have been reported to contain possible Gb3Cer binding sites [62]. Results suggested that Gb3Cer modulates MHC class II-mediated antigen presentation from B cells to helper T cells, although the molecular mechanisms of Gb3Cer-MHC class II binding are still unknown. Tumors, however, may limit MHC class I-mediated antigen presentation [63]. A recent study investigating the roles of GSLs and related enzymes in MHC class I pathways using genome-wide haploid genetic screening and CRISPR/Cas9 systems [53] found that, in the absence of signal peptide peptidase-like 3 (SPPL3) protease, high amounts of negatively charged neolacto-series GSLs interfere with the accessibility of MHC class I molecules for immune cell receptors, suppressing the activation of $\mathrm{CD} 8^{+} \mathrm{T}$ cells. In this pathway, SPPL3 catabolizes the glycosyltransferase B3GNT5, which generates neolacto-series GSLs, and controls the ability of MHC class I molecules to access their receptors. Thus, neolacto-series GSLs may affect antigen presentation and help tumor cells escape from immune surveillance [63]. In addition, the sialic acid residues on GSLs were found to be critical for MHC class I shielding [53]. The molecular basis of the interactions between GSL-enriched microdomains and antigen presentation-related molecules may provide critical information that can help in the treatment of immune disorders.

In addition to their roles in innate immune signaling, GSL-enriched microdomains are also essential in acquired immune signaling. During T-cell responses, lymphocyte functionassociated antigen-1 (LFA-1) moves into membrane microdomains upon CD4 ligation, becoming associated mainly with GM3 [54]. At this time, phosphoinositide 3-kinase (PI3K) is mainly associated with GM1, and its association with p56lck was increased. During the reaction, LFA-1 becomes primarily associated with GM1. However, the mechanisms by which these gangliosides interact (directly or indirectly) with protein molecules remain unknown. a-Series gangliosides and asialo-series gangliosides have been implicated in the function and stimulation of T-cell receptors (TCRs) on CD4-positive $\left(\mathrm{CD} 4^{+}\right)$and CD8positive $\left(\mathrm{CD}^{+}\right) \mathrm{T}$ cells, respectively [55], indicating the possibility that CD4 and CD8 interact with a-series and asialo-series gangliosides, respectively, through their common glycan structures $[55,64]$. Similarly, the ceramide structures of gangliosides may participate in these interactions. Although future studies are needed to address these possibilities, individual gangliosides may be involved in the movement of CD4 and CD8 to specific and correct locations in cell membranes $[55,64]$. 
Notch signaling is critical for T-cell development in the thymus [65]. Notch ligands, such as Dll1, may interact with GSLs through their GSL-binding motif [66], suggesting that the molecular interactions of protein receptors and ligands with GSLs may be associated with the regulation of T-cell functions. T cells play important roles in the pathogenesis of various autoimmune diseases, including systemic lupus erythematosus (SLE) [67]. GSL expression is dysregulated in $\mathrm{CD}^{+} \mathrm{T}$ cells from patients with SLE [68], and T cells from these patients show alternations in GSL recycling and turnover. Thus, GSL-enriched microdomains may be implicated in the pathogenesis of autoimmune diseases. GSLenriched microdomains interact with B-cell receptors (BCRs) as well as participating in TCR-mediated functions. Indeed, GM1-enriched microdomains associated with BCR signaling may be critical for ganglioside-related B lymphocyte functions [56,69-71]. BCRs are indispensable for the B-cell clonal selection process and their differentiation into plasma cells. GM1-enriched microdomains may be involved in the compartmentalization of different types of BCRs, such as IgM and IgD types, expressed on mature B cells [56,70], although the mechanisms by which GM1-enriched microdomains modulate BCR signaling remain to be determined.

\section{GSLs and Their Antibodies}

Although GSL and its enriched membrane microdomains modulate a diverse array of immune responses through various signaling pathways, the pathogenesis of autoimmune diseases is thought to involve immune responses to GSL antigens. Healthy human sera contain a variety of anti-GSL antibodies, suggesting that endogenous GSLs act as antigens and induce $B$ cells to produce antibodies $[72,73]$. However, infection by several pathogens, including Campylobacter jejuni and cytomegalovirus, leads to the production of autoantibodies against gangliosides. These findings suggest that autoantibodies play various pathogenic roles in autoimmune diseases, such as Guillain-Barré syndrome (GBS) [74]. The specificity of anti-GM1 antibodies in sera from patients with GBS varies, depending on clinical condition [75]. Interestingly, the specificities of the anti-LacCer monoclonal antibodies (mAbs) T5A7 and Huly-m13 differ from each other [76]. Whereas both T5A7 and Hulym13 recognize LacCer on human neutrophils, T5A7 alone recognizes LacCer on mouse neutrophils. Furthermore, Huly-m13 is capable of precipitating LacCer antigens, whereas T5A7 is not [51]. T5A7 and Huly-m13 have distinct binding regions in LacCer-enriched microdomains [76], suggesting that the antigenic specificity of GSLs is complicated in plasma membranes. Thus, the specificities of mAbs against the same GSL antigens may reflect differences in the three-dimensional structural features of GSL-enriched microdomains. A recent study using antibodies against artificially synthesized GSLs showed that fatty acid chain length correlated with GSL antigenicity [77]. Moreover, the oligosaccharide structures in GSLs influence the class switching of induced antibodies [78]. Autoantibodies against LacCer are present in patients with encephalomyeloradiculoneuropathy (EMRN) [79], suggesting that antibody-mediated immune responses to GSL antigens may be implicated in the pathogenesis of several disorders, such as EMRN.

\section{GSL-Enriched Microdomain-Mediated Apoptosis and Autophagy}

Sphingolipid- and cholesterol-rich membrane microdomains serve as platforms for the recruitment and concentration of apoptotic signaling molecules at the plasma membrane [80-83]. There are two main apoptotic pathways: the extrinsic or death receptor pathway and the intrinsic or mitochondrial pathway. During the induction of apoptosis, Fas/CD95, Fas-associated death domain (FADD)-containing protein and procaspase-8/10 (all the DISC components) are recruited into lipid microdomains. Once multimeric complexes (DISC) are formed, the number of procaspase- 8 molecules increases, resulting in the self-activation of procaspase- 8 . This results in the activation of a caspase cascade and the initiation of apoptosis [84]. The formation of clusters of apoptotic signaling molecule-enriched rafts (CASMERs) could be a major regulator of apoptotic signaling $[84,85]$. The recruitment of Bid (BH3-interacting domain death agonist) to CASMERs facilitates interactions 
between death receptor-related extrinsic apoptosis signaling and mitochondrial-related intrinsic apoptosis signaling, thereby amplifying apoptosis. CASMER formation and the compositions of CASMERs are dependent on cell types and stimulants $[85,86]$. Cholesterol is a critical constituent of lipid microdomains, with displacement of cholesterol disrupting CASMER formation [80,84]. Cancer cells contain high levels of cholesterol and cholesterolrich microdomains, making them prone to form CASMERs. Novel CASMERs can promote apoptotic machinery of tumor cells, with CASMER formation making cancer cells more vulnerable. Thus, enhancing CASMER formation may be a potential therapeutic target in cancers [84].

GSLs play pivotal roles in apoptotic pathways. GSLs form lipid microdomains in the membranes of subcellular compartments, as well as in plasma membranes. These subcellular GSL-enriched lipid microdomains mediate important signaling pathways involved in various physiological functions. GM3 and disialoganglioside GD3 are abundant components in the lipid microdomains of human lymphocytic cells $[87,88]$. The treatment of human lymphoblastoid T cells with anti-CD95/Fas triggers an association of GM3 and caspase-8, indicating that gangliosides are structural components of the membrane multimolecular signaling complex involved in the apoptosis pathway mediated by the CD95/Fas receptor [57]. GD3 is a minor ganglioside in most normal tissues but is highly expressed in a variety of tumors, resulting in its original description as a tumor-associated ganglioside [89]. GD3 interacts directly with isolated mitochondria and induces organelle swelling and the production of reactive oxygen species (ROS), cytochrome $C$, apoptosis-inducing factor (AIF) and caspase-9 [89]. Both intracellular and exogenously added GD3 were able to interact with mitochondria. GD3 induces mitochondrial permeability transition, occurring prior to apoptosis, in MH1C1 cells [90]. The opening of the permeability transition pore complex (PTPC) in mitochondria is controlled by bcl-2, which blocks apoptosis induced by both endogenous and exogenous GD3 [91]. TNF- $\alpha$ stimulates a physical association with GD3 in the mitochondria of rat hepatocytes [92]. Moreover, GD3 interacts with voltage-dependent anion channels (VDAC-1) on mitochondrial membranes. As a structural component of multi-molecular complexes that include VDAC-1, Bcl2-family proteins (Bax and t-Bid) and fission proteins, GD3 is involved in the opening of mitochondrial permeability transition pores [93]. In melanocyte, the expression of the GD3 synthase gene is oppositely regulated by TNF- $\alpha$ and cAMP [94]. Taken together, these findings indicate that GSLs play pivotal roles in apoptotic pathways.

In innate immunity, apoptosis is a self-destructive response, by which tissue-resident macrophages eliminate neutrophils from inflamed tissues. These processes are crucial for limiting injury to inflammatory tissues and the subsequent resolution of inflammation [95]. Similar to LacCer, the unique glycophospholipid, phosphatidylglucoside (PtdGlc), is highly expressed on the outer leaflet of the plasma membrane of human neutrophils [96]. However, PtdGlc and LacCer form distinct microdomains on the cells and mediate distinct signaling pathways [95]. PtdGlc has also been reported to be a marker of neutrophil differentiation $[97,98]$. Importantly, the cross-linking of PtdGlc with the anti-PtdGlc antibody induces an association between PtdGlc-enriched microdomains and Fas [95], and the anti-PtdGlc antibody induces apoptosis of human neutrophils. Thus, microdomain-mediated apoptosis is thought to be an essential process in the innate and adaptive immune systems.

Although autophagy and apoptosis represent distinct cellular processes with fundamentally different biochemical and morphological features, they are highly connected to each other $[83,99,100]$. Autophagy is triggered in response to many stresses that ultimately lead to apoptosis. In the presence of persistent stress, autophagy is unable to support cell survival, resulting in the activation of apoptosis to ensure the effective elimination of these cells without causing local inflammation [99]. Thus, apoptosis and autophagy can cooperate, antagonize or assist each other, differentially influencing the fate of cells [83]. Three distinct forms of autophagy have been identified: macroautophagy, microautophagy and chaperone-mediated autophagy [101,102]. In macroautophagy, the cell forms a doublemembrane sequestering compartment, called the phagophore. Phagophore formation is 
initiated by the ULK1 complex, the class III PtdIns 3K complex (PIK3C3) and autophagyrelated (ATG) genes (ATG5-ATG12-ATG16L complex). The expanding membrane of the phagophore closes around the cargo and separates it from the endoplasmic reticulum (ER) to form a mature autophagosome. These mature autophagosomes fuse with lysosomes, forming autophagolysosomes. Their contents are degraded by proteases, and the resulting macromolecules are transported into the cytosol for recycling [102,103]. GD3 is associated with phosphatidylinositol (3) phosphate (PtdIns3P) and microtubule-associated protein light chain 3 (LC-3) in fibroblasts, indicating the importance of GD3 in the timing of the initiation phase of autophagy and in autophagosome biogenesis [104]. GD3 is also associated with LAMP-1 at later time points, suggesting that GD3 also plays a role in the maturation of autophagosomes into autolysosomes [104]. Autophagosomes form at ER-mitochondria contact sites [105]. GD3 interacts with lipid microdomains in mitochondria-associated membranes (MAMs) and contributes to the assembly of autophagosome [106]. Thus, lipid microdomains in MAMs may play pivotal roles in the scrambling organelle that leads to the formation of autophagosomes. Autophagosomes may also assemble at ER-plasma membrane contact sites $[107,108]$. Extended synaptotagmins (E-Syts) are proteins that act as key regulators of ER-plasma membrane tethering and are involved in autophagosome biogenesis. Vacuole membrane protein 1 (VMP1), which is enriched in ER microdomains, promotes the association of the class III PtdIns 3-kinase complex (PIK3C3) with E-Sytcontaining domains, enhancing PtdIns3P synthesis $[107,108]$. These findings suggest that contacts between the ER and organelles are indispensable in autophagy and organelle biogenesis. ER-driven contacts with, for example, the plasma and mitochondrial membranes, may act as local platforms for PIK3C3. MAMs are expected to be important targets for the treatment of autophagy-related diseases. The determination of the involvement of GSLs with the formation of a platform containing autophagy-related proteins is essential in the development of novel treatments for many human diseases, such as cancer and neurodegenerative diseases, including Parkinson's disease, Alzheimer's disease and amyotrophic lateral sclerosis [109].

\section{GSLs as Immunomodulators}

As mentioned above, GSL-enriched microdomains transduce signals into cells through receptors and signaling molecules, mediating a number of physiological functions. Exogenously added GSLs alter receptor/signaling molecule-mediated cellular signaling (Table 2). Therefore, understanding the mechanisms by which exogenous GSLs modulate immunological functions is linked to the development of therapeutic agents for a number of diseases. To date, the roles of exogenous gangliosides in the immunological functions mediated by TLRs have been investigated. The preincubation of monocytes or immature dendritic cells (DCs) derived from peripheral blood mononuclear cells (PBMCs) with GM1, GD1a and GD1b was found to inhibit the production of cytokines, such as IL-6, IL-12 and TNF- $\alpha$, through a broad range of TLRs, including TLR2, TLR3, TLR4, TLR6 and TLR7/8 [110]. In addition, gangliosides were found to upregulate the expression of the TLR signaling inhibitor, IL-1 receptor associated kinase-M (IRAK-M), without inducing cytokine production. GD1a and GM1 were shown to reduce the LPS-induced biological effects in PC12 and epithelial cells, respectively [111], and to prevent the LPS-induced translocation of TLR4 into membrane microdomains, suggesting that GD1a and GM1 protect cells against LPS. The pretreatment of a mouse macrophage-like cell line, Raw 264.7, with sulfated galactocerebroside (sulfatide, SM4) was found to hinder LPS-induced TLR4 colocalization with CTxB-positive ganglioside-rich microdomains, suppressing the secretion of a sepsis mediator, high mobility group box 1 (HMGB1) [112]. GSLs are also thought to modulate receptor-mediated signaling by binding to these receptors (Table 2). For example, globotetraosylceramide (Gb4Cer) from vascular endothelial cells inhibited LPS binding to TLR4 and attenuated TLR4-MD-2-mediated LPS signaling [113]. In contrast, the treatment of mouse bone marrow-derived macrophages (BMDMs) and human monocytes with Gb3Cer/Gb4Cer was found to enhance TLR4-mediated inflammation, suggesting that the 
elevation of Gb3Cer/Gb4Cer by consumption of a high-fat diet positively regulates TLR4mediated inflammatory responses [114]. Further studies are required to better understand the mechanisms underlying the binding of Gb4Cer to the TLR4-MD-2 complex. In addition, differences in molecular complex formation and receptor expression levels among cell types might affect GSL-receptor binding and signaling. Recently, the effect of GM3 on TLR4 signaling was reported to depend on the fatty acid structure of GM3 [115]. Interestingly, GM3 species containing saturated very long-chain fatty acids (C22:0, C24:0, hC24:0) enhanced LPS/HMGB1-associated TLR4 signaling in monocytes, whereas GM3 containing long-chain fatty acids (C16:0, C18:0) or unsaturated very long- chain fatty acids (C24:1) inhibited this activation. More recently, it was reported that C12 or C16-SM4 activates TLR4-MD-2 in mouse macrophages, whereas those GSLs antagonize TLR4-MD-2 activation in a human macrophage-like cell line (PMA-differentiated THP-1) [116]. $\beta$-GlcCer was shown to act as an endogenous ligand for macrophage inducible C-type lectin (Mincle) and an immunostimulatory factor in response to cell damage [117]. A further understanding of the mechanisms by which different molecular species of GSLs modulate immune receptors as agonists/antagonists may suggest new therapeutic strategies for several disorders.

Table 2. GSLs as immune regulators.

\begin{tabular}{|c|c|c|}
\hline GSLs & Immune Functions & Ref. No. \\
\hline GM1, GD1a, GD1b & $\begin{array}{l}\text { Inhibition of TLRs (TLR2, 3, 4,6 and 7/8)-mediated IL-6, IL-12 and } \\
\text { TNF- } \alpha \text { production in monocytes and immature DCs }\end{array}$ & [110] \\
\hline GM1, GD1a & Inhibition of LPS-induced biological effects in PC12 and epithelial cells & [111] \\
\hline SM4 & $\begin{array}{l}\text { Inhibition of LPS-induced TLR4 colocalization with CTxB-positive } \\
\text { ganglioside-rich microdomains and HMGB1 secretion in Raw } 264.7 \\
\text { cells }\end{array}$ & [112] \\
\hline Gb4Cer & $\begin{array}{l}\text { Inhibition of LPS binding to TLR4 and attenuation of } \\
\text { TLR4-MD-2-mediated LPS signaling in vascular endothelial cells }\end{array}$ & [113] \\
\hline Gb3Cer/Gb4Cer & $\begin{array}{l}\text { Enhancement of TLR4-mediated inflammation in mouse BMDMs and } \\
\text { human monocytes }\end{array}$ & [114] \\
\hline $\begin{array}{l}\text { GM3 (C22:0, C24:0 or hC24:0 fatty } \\
\text { acid) }\end{array}$ & Enhancement of LPS/HMGB1-associated TLR4 signaling in monocytes & [115] \\
\hline $\begin{array}{c}\text { GM3 (C16:0, C18:0 or C24:1 fatty } \\
\text { acid) }\end{array}$ & Inhibition of LPS/HMGB1-associated TLR4 signaling in monocytes & [115] \\
\hline SM4 (C12 or C16 fatty acid) & Activation of TLR4-MD-2 in mouse macrophages & [116] \\
\hline SM4 (C12 or C16 fatty acid) & $\begin{array}{l}\text { Antagonizing effect on TLR4-MD-2 activation in human } \\
\text { macrophage-like PMA-differentiated THP-1 cells }\end{array}$ & [116] \\
\hline$\beta$-GlcCer & $\begin{array}{l}\text { Immunostimulatory factor upon cell damage, endogenous ligand for } \\
\text { Mincle }\end{array}$ & [117] \\
\hline LacCer (C24:0 or C24:1 fatty acid) & $\begin{array}{c}\text { Enhancement of activated Lyn-mediated neutrophil functions } \\
\text { (chemotaxis, phagocytosis and superoxide generation) in } \\
\text { DMSO-treated HL-60 cells }\end{array}$ & {$[18,20,51,61]$} \\
\hline LacCer (C24:0 or C24:1 fatty acid) & $\begin{array}{l}\text { Induction of } \beta \text {-glucan binding-dependent SHP-1 phosphorylation } \\
\text { through Lyn and the resulting reduction of Fc } \gamma \text { RIIA affinity in } \\
\text { DMF-treated HL-60 cells }\end{array}$ & [118] \\
\hline Gangliosides & $\begin{array}{l}\text { Facilitation of the development of regulatory T-cell activity in murine } \\
\text { BMDCs }\end{array}$ & [119] \\
\hline Gangliosides (tumor derived) & Inhibition of lytic function in CD8 ${ }^{+}$CTLs & [120] \\
\hline Gangliosides & $\begin{array}{l}\text { Cooperative role with IFN- } \gamma \text { to inhibit the immnostimulatory activity } \\
\text { of DCs }\end{array}$ & [121] \\
\hline GQ1b & $\begin{array}{l}\text { Facilitation of T-cell-mediated cytokine production, which possibly } \\
\text { involves indirect enhancement of B-cell production of Ig }\end{array}$ & [122] \\
\hline
\end{tabular}


Exogenous LacCer has been found to be involved in cell adhesion, angiogenesis, the generation of ROS and inflammation [123,124]. It has been reported that, in human neutrophils and monocytes, exogenously added LacCer upregulates the expression of $\mathrm{CD} 11 \mathrm{~b} / \mathrm{CD} 18$ and promotes their adhesion to the endothelium and subsequent entry into the endothelium, inducing inflammation and atherosclerosis [123,125]. Moreover, exogenously added LacCer activates cytosolic phospholipase A2 (cPLA2) to generate arachidonic acid, a precursor to prostaglandins that mediate inflammation $[123,125]$. The human acute myeloid leukemia cell line HL-60 can be differentiated into cells of the neutrophil lineage by incubation with dimethyl sulfoxide (DMSO). These D-HL-60 cells, however, are unable to exert LacCer-mediated innate immune responses [25,51], because their plasma membranes contain few very long fatty acid-containing LacCers (C24-LacCer) [18]. Importantly, exogenously added C24- but not C16-LacCer directly interacts with Lyn through the binding of the C24 fatty acid chains to the palmitic chains of Lyn [61]. This resulted in the reconstruction of LacCer-enriched microdomains, which are coupled to several signaling molecules. These reconstructed C24-LacCer-containing microdomains can act as signaling platforms for several neutrophil functions, including chemotaxis, phagocytosis and superoxide generation. In contrast to the previously known properties of $\beta$-glucans [126], $\beta$-glucan binding to C24-LacCer-containing microdomains was found to trigger the Lyn-mediated phosphorylation of phosphatase SHP-1 and to reduce Fc $\gamma$ RIIA affinity in dimethylformamide (DMF)-treated HL-60 cells [118]. These findings suggest that $\beta$-glucan binding to C24LacCer leads to inside-out signals that reduce Fc $\gamma$ RIIA affinity. LacCer can bind to a variety of PAMPs, including $\beta$-glucan [64]. Exogenous C24-LacCer enhanced the phagocytosis not only of $\beta$-glucan-rich zymosan particles but also of mycobacteria [20]. Therefore, exogenous LacCer may alter the microenvironment of microdomains and positively or negatively regulate microdomain-associated immune receptor signaling.

CD1d presents GSLs as antigens to cells of the innate immune system, such as natural killer T (NKT) cells. These cells are involved in the regulation of innate and adaptive immune responses against cancers, infectious diseases and inflammatory diseases [127]. A marine sponge-derived $\alpha$-GalCer was shown to be a lipid antigen molecule that activates NKT cells [128] and enhances immune responses to various infectious microorganisms and cancers [129]. $\alpha$-Linked glycosylceramides are identified as endogenous ligands on NKT cells [130]. These findings suggest that, as a modulator of NKT cells, GSLs can be therapeutic in patients with several types of immune disorders.

The pretreatment of murine bone marrow-derived DCs (BMDCs) with gangliosides was found to facilitate the development of regulatory T-cell activity [119]. Tumor-derived gangliosides suppress lytic function in $\mathrm{CD}^{+}$cytotoxic $\mathrm{T}$ lymphocytes (CTLs) by preventing the TCR-induced release of lytic granules [120]. Moreover, gangliosides cooperate with interferon (IFN)- $\gamma$ to inhibit the immunostimulatory activity of DCs in an inflammatory environment [121]. In contrast, the ganglioside GQ1b facilitates cytokine production by T cells, without altering cytokine production by B cells and monocytes [122]. The co-culture of B cells with GQ1b-treated T cells enabled B cells to produce immunoglobulin (Ig). GQ1b may indirectly enhance the B-cell production of Ig by inducing the T-cell production of IL-6 and IL-10. Thus, extracellular or exogenously added gangliosides are likely to regulate adaptive immune responses.

\section{GSL-Enriched Microdomains as Entry Sites for Pathogens and Toxins}

As mentioned above, GSL-enriched microdomains serve as signaling platforms for a variety of physiological functions through their cis- or trans-interactions with protein receptors. GSL-enriched microdomains provide the entry sites for foreign materials by binding directly to pathogens and toxins. To date, a large number of pathogens and toxins have been reported to gain access to host cells through their trans-interaction with GSLs. For example, polyomavirus must bind to GD1a and GT1b to enter human erythrocytes [131]. In addition, the N-terminal domain (NTD) of the SARS-coronavirus 2 (SARS-CoV-2) spike protein has a ganglioside-binding domain $[132,133]$, and angiotensin-converting enzyme-2 (ACE2), a 
major receptor for SARS-CoV-2, colocalizes with GM1 [134]. Because the mechanisms by which GM1-enriched microdomains are associated with ACE2 remain unclear, the determination of these molecular mechanisms may be critical in the development of treatments for COVID-19. Shiga toxin (Stx) and its verotoxin B subunit have been found to bind preferably to Gb3Cer expressed on human epithelial and endothelial cells [135-138]. Based on current knowledge, Stx subtypes Stx1a and Stx2a are known to prevalently bind to Gb3Cer from primary human brain microvascular endothelial cells (pHBMECs) and primary human renal glomerular endothelial cells (pHRGECs), respectively, although both Stx1a and Stx2a show significant lower binding to Gb4Cer $[139,140]$. Gb3Cer predominantly distributes in the DRMs of both pHBMECs and pHRGECs $[139,140]$. Such preferential distribution of Gb3Cer to DRMs suggests an association of Gb3Cer with membrane microdomains and appearance of the major Stx receptor in a microdomain environment [140]. In addition, the prevalent lipoforms of Gb3Cer and Gb4Cer in pHBMECs and pHRGECs were those with Cer (d18:1, C16:0), Cer (d18:1, C22:0) and Cer (d18:1, C24:1/C24:0) [140]. More recently, Gb3Cer and Gb4Cer with Cer (d18:1, C16:0), Cer (d18:1, C22:0) and Cer (d18:1, $\mathrm{C} 24: 1 / \mathrm{C} 24: 0)$ were identified as the dominant lipoforms of primary human renal cortical epithelial cells (pHRCEpiCs) [141]. Gb3Cer and Gb4Cer lipoforms carrying a C24:1 or C24:0 fatty acid chain could be involved in the interdigitation between the fatty acyl chains of the two leaflets of the plasma membrane microdomains [141]. Stxs are multifunctional proteins capable of activating multiple stress signaling pathways, resulting in apoptosis, autophagy or induction of innate immune responses [142,143]. Therefore, long acyl chain-containing Gb3Cer/Gb4Cer in the plasma membrane microdomains may play critical roles in multiple Stxs-mediated immune responses. Although Gb4Cer is not involved in the binding or internalization of parvovirus B19 (B19V), Gb4Cer is important in a post-internalization step prior to the delivery of viral DNA into the nucleus [144]. Streptococcus suis SadP adhesin from systemic subtype $\mathrm{P}_{\mathrm{N}}$ strains binds to Gb4Cer through its amino acid asparagine 285 [145]. Asialo GM1 (GA1) expressed by epithelial cells binds to Pseudomonas aeruginosa, Bifidobacterium bifidum and Lactobacillus [146,147], and GM1 was found to bind to simian virus 40 (SV40) [131] and Brucella suis [148]. This ganglioside can bind to CTxB [149,150], and GM1 expressed on epithelial cells binds to Escherichia coli enterotoxin [151]. GM1 containing long acyl chains is essential for the membrane invaginations of SV40 [152]. However, GM1 species containing unsaturated or short acyl chains is reported to be critical for the GM1-mediated transcytosis of CTxB [153]. The recent study by Kabbania demonstrated that the clustering of GM1 is required for CTxBinduced membrane curvature in model membranes, but the ceramide structure is not likely to play a determinant role in this mechanism [154]. Therefore, pathogen/toxin-induced GM1-mediated physiological functions may be altered by the structural differences of the GM1 ceramide portion. In addition to GM1, other gangliosides, particularly fucosylated GM1 (Fuc-GM1), are involved in binding to CTB $[155,156]$. Galactosylceramide (GalCer) binds to the influenza A virus (IAV) [157] and the norovirus GII.4 [158]. In addition to GalCer, Gb3Cer and GM3 were shown to act as entry receptors of human immunodeficiency virus (HIV-1) [159], suggesting that GSL-enriched microdomains are involved in stabilizing HIV-1 attachment to the cell surface and in the promotion of co-receptor recruitment [160-162]. Intracellular parasites, such as Mycobacterium tuberculosis, enter into host phagocytes via membrane microdomains, which enable them to survive inside cells [163]. These findings suggest that, to promote their survival, intracellular parasites exploit GSL-enriched microdomains to manipulate host microbicidal pathways. LacCer, which is expressed on intestinal epithelial cells as well as on neutrophils, binds to various microorganisms, such as Mycobacterium avium-intracellulare complex (MAC), M. tuberculosis, Candida albicans, Bacillus dysenteriae, Bordetella pertussis, E. coli and Propionibacterium freudenreichii [64]. In addition, the Gram-negative bacterium Edwardsiella tarda, a causative agent of economic damage in aquaculture, can bind LacCer but not GlcCer [164]. LacCer is a major GSL component in human and bovine milk [165], indicating that milk-derived LacCer may block pathogen binding in the intestines, protecting the host from invading 
pathogens. The finding that several species of microorganisms bind to LacCer suggests the presence of common structural patterns on the membranes of these microorganisms that can be recognized by LacCer-enriched microdomains. Indeed, LacCer-enriched microdomains recognize PAMPs differentially expressed by fungi and mycobacteria $[20,60,64]$. The pathogenic fungus-derived $\beta$-glucan, CSBG, is composed of a $\beta-1,3$ glucopyranose glucan backbone, with $\beta-1,6$ long glucopyranose side chains and $\beta-1,3$ monoglucopyranose branches [166]. GSLs with a terminal galactose residue, such as GalCer, LacCer and Gb3Cer, are essential for binding to CSBG [60]. Similarly, these types of GSLs bind to yeast-derived PGG-glucan [167], which has a structure similar to that of CSBG [168]. In contrast, the glycolipid lipoarabinomannan (LAM), which is abundantly expressed on the cell walls of mycobacteria [169], contains a mannan core structure, consisting of a linear backbone of $\alpha-1,6$ mannopyranose with $\alpha-1,2$ mannopyranose side branches [170]. Although this structure is a common motif among mycobacterial species [170], the LAM of pathogenic mycobacteria, including $M$. tuberculosis, has a terminal mannose cap, ManLAM, whereas the LAM of non-pathogenic species has a terminal phospho-myoinositol cap (PILAM) or no cap LAM [171]. LacCer binds to both ManLAM and PILAM [20], suggesting that LacCer-enriched microdomains recognize the common $\alpha-1,2$ monomannose side branching mannan core of LAM present in mycobacterial species. GSL-enriched microdomains may recognize the common three-dimensional structures among different PAMPs through carbohydrate-carbohydrate interactions. The sugar moieties of gangliosides interact with the polysaccharide moieties of Shigella LPS [172], thereby facilitating the binding of bacteria to human $\mathrm{CD}^{+} \mathrm{T}$ cells. These findings suggest that specific carbohydrate-carbohydrate interactions between the sugar moieties of GSLs and PAMPs may be implicated in various infectious diseases.

\section{Intracellular Interactions between GSL-Enriched Microdomains and Pathogens}

GSL-enriched microdomains in plasma membranes function as entry sites for pathogens and toxins. The uptake of pathogens into cells leads to nascent phagosome formation, resulting in the fusion of lysosomes to pathogen-containing phagosomes (phagosome maturation). However, the molecular mechanisms by which GSL-enriched microdomains interact intracellularly with pathogens, such as during the phagosome maturation process, remain to be elucidated. Recently, genome-wide CRISPR screening showed that the enzymes ceramide synthase, fatty acid elongase and sphingomyelin synthase 1 (SMS1) are involved in phagocytosis [173]. In addition, sphingomyelin biosynthesis was reported to be critical for the uptake of M. tuberculosis by human macrophages [174]. Quantitative lipidomic analysis demonstrated that ceramide synthase 2 (CerS2) is enriched in early phagosomes and that the amounts of C24 ceramides are increased in late phagosomes [175]. LacCer-enriched microdomains in human neutrophils are essential not only in the uptake of bacteria but also in the maturation process of bacteria-containing phagosomes [20,25,51]. Interestingly, the pathogenic mycobacteria, M. tuberculosis and MAC, were found to inhibit the association of LacCer-enriched microdomains with the signaling molecule Hck, leading to phagosome maturation arrest. In addition, SM is distributed as clusters in the inner leaflet of plasma membranes of human neutrophils [2], suggesting the involvement of SM in intracellular events. More recently, SM was reported to be exposed on the cytosolic side of damaged phagosomal membranes around Salmonella or Listeria, with galectin-8 localizing to the phagosomal membranes $[176,177]$. The cytosolic exposure of SM by $\mathrm{Ca}^{2+}$ activated scramblase was recently reported to mediate lysosomal repair independently of the endosomal sorting complex required for the transport complex (ESCRT) [178]. Although the mechanisms by which pathogenic mycobacteria survive inside host cells remain unclear [179], an exploration of the involvement of cross-talk between GSL-enriched microdomains and other sphingolipids in intracellular events, such as phagosome maturation, may be key to the development of new treatments for mycobacterial infections.

Some viruses exploit GSLs to enter into and survive inside host cells. Indeed, GM3 was reported to be essential for the replication of dengue virus (DENV) [180]. SM, Cer 
and GlcCer are enriched in Zika virus (ZIKV) particles [181]. Patients who are infected with ZIKV and develop the neurological autoimmune disorder Guillain-Barré syndrome (GBS) [182] have high levels of antibodies to GSLs: GM1, GM2, GA1, GD1a, GD1b and various other gangliosides $[183,184]$. Although GSLs are required for the replication of ZIKV, they are not necessary for virus entry into host cells. ZIKV alters host lipid composition, modulating sphingolipid pathways [185], and may therefore manipulate ceramide-related metabolism. Mutations in SARS-CoV-2, a new type of coronavirus, result in alterations in the spike protein recognized by host ACE-2 receptors, allowing the virus to escape from host recognition and elimination systems [186]. SARS-CoV-2 may bind to the sialic acid moieties of the gangliosides expressed on host cell surfaces [134]. The concentrations of circulating sphingosine-1 phosphate (S1P) were found to be lower in patients with more severe clinical scores $[187,188]$. Because S1P is associated with the induction of inflammatory responses, the S1P analogue FTY720 (fingolimod), which acts as a S1P receptor antagonist, may suppress hyper-inflammation, although the immunosuppressive effects of FTY720 alone are not negligible. Together, GSL-enriched microdomains and sphingolipid-derived metabolites may be essential for infection by emerging viruses, such as SARS-CoV-2, and may therefore be a target for the treatment of viral infections.

The infection of mouse alveolar macrophages with Pseudomonas aeruginosa results in the activation of acid sphingomyelinase (aSMase) and the formation of ceramide-enriched microdomains [189]. These ceramide-enriched microdomains are required for the P. aeruginosa-induced activation of nicotinamide adenine dinucleotide phosphate (NADPH) oxidase, which produces reactive oxygen species (ROS). ASMase activation leads to the internalization of $P$. aeruginosa and the induction of apoptosis. P. aeruginosa-derived phospholipase $C$ and alkaline ceramidase are involved in sphingolipid metabolism [190-192]. Chlamydia psittaci is able to obtain sphingolipids from host cells, thereby surviving in host cells [193,194], whereas C. trachomatis recruits CERT, SMS1, SMS2 and VAP-A to inclusion bodies, acquiring ceramide and metabolizing it to SM [195]. C. trachomatis is able to proliferate in SMS1/SMS2 double-knockout HeLa cells but not in SMS1/SMS2/CERT triple-knockout cells [196]. C. trachomatis can exploit the signaling pathway involving Akt and its $160 \mathrm{kDa}$ substrate AS160 to increase the delivery of sphingolipids to inclusion bodies through Rab14 [197]. These reports suggest that several intracellular pathogens, such as Pseudomonas and Chlamydia, control sphingolipid metabolism pathways and vesicular transport.

Gram-negative pathogenic bacteria are known to use the type III secretion system (T3SS) to induce pore formation on host membranes [198,199]. Salmonella uses T3SS to rupture phagosomal membranes $[176,177]$, releasing internalized bacteria into the cytoplasmic region of host cells and inducing autophagy (xenophagy) to eliminate these bacteria [200,201]. Recently, LC3-associated phagosomes (LAPsomes) were shown to be a novel form of non-canonical autophagy [202,203]. LAPsomes may function as regulators of the immune system. Indeed, LAPsome-deficient macrophages show reduced efferocytosis activity, and mice with LAPsome-deficient macrophages develop a lupus-like autoimmune disorder [204]. In addition to efferocytosis, microbicidal activity is reduced in LAPsomedeficient macrophages [205]. However, there is less evidence regarding the relationships between sphingolipids and LAPsomes. Some proteins in Legionella pneumophila are similar to eukaryotic sphingolipid metabolic enzymes [206-208]. In particular, L. pneumophila impairs autophagy by preventing host sphingosine metabolism through an S1P lyase, LpSpl. Salmonella suppresses Akt/mTOR signaling-mediated autophagy responses by recruiting focal adhesion kinase (FAK) to Salmonella-containing vacuoles (SCV) [209]. Together, these findings indicate that intracellular pathogens use GSL-enriched microdomains and sphingolipid metabolism to survive inside host cells. To eliminate internalized pathogens, GSL-enriched microdomain-associated signaling and sphingolipid metabolism pathways may be essential for vesicular transport and autophagy. However, the mechanisms involving the interplay between these two pathways remain to be determined. 


\section{Perspective}

A huge number of investigations have been carried out to elucidate the roles of GSL-enriched microdomains in a wide range of physiological functions. In particular, research advances in the field of immunology provide insights into the mechanisms of how GSL-enriched microdomains modulate immune functions through multiple pathways. At present, investigators have understood the molecular mechanisms by which specialized GSL-enriched microdomains directly interact in cis with various protein receptors and mediate immune signaling. A better understanding of the mechanism of interaction between GSL-enriched microdomains and protein receptors in different aspects of pathogenesis may provide novel therapeutic targets for many types of diseases. GSL-enriched microdomains directly interact in trans with pathogens and their toxins and provide pathogens with entry sites into host cells. Therefore, a further characterization of the binding specificities of GSLs to pathogen-associated molecules would lead to the design and development of new drugs that prevent infection. Similarly, the characterization of anti-GSL antibodies may bring a significant benefit to the elucidation of the pathogenic mechanism of autoimmune diseases. In recent years, advanced technologies, such as genome-wide screening using CRISPR/Cas9 systems, have been applied to the studies of GSL functions [210-212]. The lipidomes and transcriptomes of individual human cells by coupling high-resolution mass spectrometry imaging to single-cell transcriptomics may also open a new paradigm for unravelling unidentified functions of GSLs [213]. These advanced technologies, along with anti-GSL antibodies, may help to better understand the functions of GSL-enriched microdomains and may lead to the development of new pharmacological drugs for the treatment of various immune disorders.

Author Contributions: N.Y. and K.H. contributed equally to the conceptualization, writing, review and editing of the manuscript. T.H. and E.O. reviewed and edited the manuscript. K.I. supervised and contributed to funding acquisition. H.N. contributed to the conceptualization, writing, review, editing of the manuscript and funding acquisition. All authors have read and agreed to the published version of the manuscript.

Funding: This study was supported in part by the Foundation of Strategic Research Projects in Private Universities (Grants-in-Aid S1311011); AMED (Grant Numbers JP21gm0910006h0106 and JP20ae0101068h0005 to K.I.); JSPS KAKENHI (Grant Numbers JP17K10031 and JP21K06086 to H.N., JP20K17471 to K.H.); and The Promotion and Mutual Aid Corporation for Private Schools of Japan (Scholarship Fund for Young/Women Researchers).

Conflicts of Interest: The authors declare no conflict of interest.

\section{References}

1. Pike, L.J. Rafts defined: A report on the Keystone Symposium on Lipid Rafts and Cell Function. J. Lipid Res. 2006, 47, 1597-1598. [CrossRef]

2. Murate, M.; Abe, M.; Kasahara, K.; Iwabuchi, K.; Umeda, M.; Kobayashi, T. Transbilayer distribution of lipids at nano scale. J. Cell Sci. 2015, 128, 1627-1638. [CrossRef] [PubMed]

3. Kaga, N.; Kazuno, S.; Taka, H.; Iwabuchi, K.; Murayama, K. Isolation and mass spectrometry characterization of molecular species of lactosylceramides using liquid chromatography-electrospray ion trap mass spectrometry. Anal. Biochem. 2005, 337, 316-324. [CrossRef]

4. Hakomori, S. Structure, organization, and function of glycosphingolipids in membrane. Curr. Opin. Hematol. 2003, 10, 16-24. [CrossRef] [PubMed]

5. Held, W.; Mariuzza, R.A. Cis-trans interactions of cell surface receptors: Biological roles and structural basis. Cell Mol. Life Sci. 2011, 68, 3469-3478. [CrossRef] [PubMed]

6. Hakomori, S. Glycosphingolipids in cellular interaction, differentiation, and oncogenesis. Annu. Rev. Biochem. 1981, 50, 733-764. [CrossRef]

7. Mukherjee, S.; Maxfield, F.R. Membrane domains. Annu. Rev. Cell Dev. Biol. 2004, 20, 839-866. [CrossRef] [PubMed]

8. Brown, D.A.; London, E. Structure of detergent-resistant membrane domains: Does phase separation occur in biological membranes? Biochem. Biophys. Res. Commun. 1997, 240, 1-7. [CrossRef]

9. Iwabuchi, K.; Handa, K.; Hakomori, S. Separation of "glycosphingolipid signaling domain" from caveolin-containing membrane fraction in mouse melanoma B16 cells and its role in cell adhesion coupled with signaling. J. Biol Chem. 1998, 273, 33766-33773. [CrossRef] 
10. Iwabuchi, K.; Yamamura, S.; Prinetti, A.; Handa, K.; Hakomori, S. GM3-enriched microdomain involved in cell adhesion and signal transduction through carbohydrate-carbohydrate interaction in mouse melanoma B16 cells. J. Biol. Chem. 1998, 273, 9130-9138. [CrossRef]

11. Sonnino, S.; Prinetti, A.; Mauri, L.; Chigorno, V.; Tettamanti, G. Dynamic and structural properties of sphingolipids as driving forces for the formation of membrane domains. Chem. Rev. 2006, 106, 2111-2125. [CrossRef] [PubMed]

12. Jacobson, K.; Sheets, E.D.; Simson, R. Revisiting the fluid mosaic model of membranes. Science 1995, 268, 1441-1442. [CrossRef]

13. Hakomori, S.; Handa, K.; Iwabuchi, K.; Yamamura, S.; Prinetti, A. New insights in glycosphingolipid function: "glycosignaling domain", a cell surface assembly of glycosphingolipids with signal transducer molecules, involved in cell adhesion coupled with signaling. Glycobiology 1998, 8, xi-xix. [CrossRef] [PubMed]

14. Singh, R.D.; Puri, V.; Valiyaveettil, J.T.; Marks, D.L.; Bittman, R.; Pagano, R.E. Selective caveolin-1-dependent endocytosis of glycosphingolipids. Mol. Biol. Cell 2003, 14, 3254-3265. [CrossRef] [PubMed]

15. Komura, N.; Suzuki, K.G.; Ando, H.; Konishi, M.; Koikeda, M.; Imamura, A.; Chadda, R.; Fujiwara, T.K.; Tsuboi, H.; Sheng, R.; et al. Raft-based interactions of gangliosides with a GPI-anchored receptor. Nat. Chem. Biol. 2016, 12, 402-410. [CrossRef] [PubMed]

16. Kusumi, A.; Fujiwara, T.K.; Tsunoyama, T.A.; Kasai, R.S.; Liu, A.A.; Hirosawa, K.M.; Kinoshita, M.; Matsumori, N.; Komura, N.; Ando, H.; et al. Defining raft domains in the plasma membrane. Traffic 2020, 21, 106-137. [CrossRef]

17. Kinoshita, M.; Suzuki, K.G.; Matsumori, N.; Takada, M.; Ano, H.; Morigaki, K.; Abe, M.; Makino, A.; Kobayashi, T.; Hirosawa, K.M.; et al. Raft-based sphingomyelin interactions revealed by new fluorescent sphingomyelin analogs. J. Cell Biol. 2017, 216, 1183-1204. [CrossRef]

18. Iwabuchi, K.; Prinetti, A.; Sonnino, S.; Mauri, L.; Kobayashi, T.; Ishii, K.; Kaga, N.; Murayama, K.; Kurihara, H.; Nakayama, H.; et al. Involvement of very long fatty acid-containing lactosylceramide in lactosylceramide-mediated superoxide generation and migration in neutrophils. Glycoconj. J. 2008, 25, 357-374. [CrossRef]

19. Fujita, A.; Cheng, J.; Fujimoto, T. Segregation of GM1 and GM3 clusters in the cell membrane depends on the intact actin cytoskeleton. Biochim. Biophys. Acta 2009, 1791, 388-396. [CrossRef]

20. Nakayama, H.; Kurihara, H.; Morita, Y.S.; Kinoshita, T.; Mauri, L.; Prinetti, A.; Sonnino, S.; Yokoyama, N.; Ogawa, H.; Takamori, K.; et al. Lipoarabinomannan binding to lactosylceramide in lipid rafts is essential for the phagocytosis of mycobacteria by human neutrophils. Sci. Signal. 2016, 9, ra101. [CrossRef]

21. Pralle, A.; Keller, P.; Florin, E.L.; Simons, K.; Horber, J.K. Sphingolipid-cholesterol rafts diffuse as small entities in the plasma membrane of mammalian cells. J. Cell Biol. 2000, 148, 997-1008. [CrossRef] [PubMed]

22. Suzuki, K.G.; Fujiwara, T.K.; Sanematsu, F.; Iino, R.; Edidin, M.; Kusumi, A. GPI-anchored receptor clusters transiently recruit Lyn and G alpha for temporary cluster immobilization and Lyn activation: Single-molecule tracking study 1. J. Cell Biol. 2007, 177, 717-730. [CrossRef]

23. Saxena, K.; Zimmermann, P.; Schmidt, R.R.; Shipley, G.G. Bilayer properties of totally synthetic C16:0-lactosyl-ceramide. Biophys. J. 2000, 78, 306-312. [CrossRef]

24. Ferraretto, A.; Pitto, M.; Palestini, P.; Masserini, M. Lipid domains in the membrane: Thermotropic properties of sphingomyelin vesicles containing GM1 ganglioside and cholesterol. Biochemistry 1997, 36, 9232-9236. [CrossRef] [PubMed]

25. Iwabuchi, K.; Nagaoka, I. Lactosylceramide-enriched glycosphingolipid signaling domain mediates superoxide generation from human neutrophils. Blood 2002, 100, 1454-1464. [CrossRef] [PubMed]

26. Róg, T.; Orłowski, A.; Llorente, A.; Skotland, T.; Sylvänne, T.; Kauhanen, D.; Ekroos, K.; Sandvig, K.; Vattulainen, I. Interdigitation of long-chain sphingomyelin induces coupling of membrane leaflets in a cholesterol dependent manner. Biochim. Biophys. Acta 2016, 1858, 281-288. [CrossRef] [PubMed]

27. Skotland, T.; Sandvig, K. The role of PS 18:0/18:1 in membrane function. Nat. Commun. 2019, 10, 2752. [CrossRef] [PubMed]

28. Arumugam, S.; Schmieder, S.; Pezeshkian, W.; Becken, U.; Wunder, C.; Chinnapen, D.; Ipsen, J.H.; Kenworthy, A.K.; Lencer, W.; Mayor, S.; et al. Ceramide structure dictates glycosphingolipid nanodomain assembly and function. Nat. Commun. 2021, $12,3675$. [CrossRef]

29. Kabayama, K.; Sato, T.; Saito, K.; Loberto, N.; Prinetti, A.; Sonnino, S.; Kinjo, M.; Igarashi, Y.; Inokuchi, J. Dissociation of the insulin receptor and caveolin-1 complex by ganglioside GM3 in the state of insulin resistance. Proc. Natl. Acad. Sci. USA 2007, 104, 13678-13683. [CrossRef]

30. Coskun, U.; Grzybek, M.; Drechsel, D.; Simons, K. Regulation of human EGF receptor by lipids. Proc. Natl. Acad. Sci. USA 2011, 108, 9044-9048. [CrossRef]

31. Yamakawa, D.; Katoh, D.; Kasahara, K.; Shiromizu, T.; Matsuyama, M.; Matsuda, C.; Maeno, Y.; Watanabe, M.; Nishimura, Y.; Inagaki, M. Primary cilia-dependent lipid raft/caveolin dynamics regulate adipogenesis. Cell Rep. 2021, 34, 108817. [CrossRef]

32. Ansell, T.B.; Song, W.; Sansom, M.S.P. The Glycosphingolipid GM3 Modulates Conformational Dynamics of the Glucagon Receptor. Biophys. J. 2020, 119, 300-313. [CrossRef]

33. Dam, D.H.M.; Wang, X.Q.; Sheu, S.; Vijay, M.; Shipp, D.; Miller, L.; Paller, A.S. Ganglioside GM3 Mediates Glucose-Induced Suppression of IGF-1 Receptor-Rac1 Activation to Inhibit Keratinocyte Motility. J. Investig. Dermatol. 2017, 137, 440-448. [CrossRef]

34. Mutoh, T.; Tokuda, A.; Miyadai, T.; Hamaguchi, M.; Fujiki, N. Ganglioside GM1 binds to the Trk protein and regulates receptor function. Proc. Natl. Acad. Sci. USA 1995, 92, 5087-5091. [CrossRef] 
35. Ichikawa, N.; Iwabuchi, K.; Kurihara, H.; Ishii, K.; Kobayashi, T.; Sasaki, T.; Hattori, N.; Mizuno, Y.; Hozumi, K.; Yamada, Y.; et al. Binding of laminin-1 to monosialoganglioside GM1 in lipid rafts is crucial for neurite outgrowth. J. Cell Sci. 2009, 122, $289-299$. [CrossRef]

36. Chiricozzi, E.; Biase, E.D.; Maggioni, M.; Lunghi, G.; Fazzari, M.; Pome, D.Y.; Casellato, R.; Loberto, N.; Mauri, L.; Sonnino, S. GM1 promotes TrkA-mediated neuroblastoma cell differentiation by occupying a plasma membrane domain different from TrkA. J. Neurochem. 2019, 149, 231-241. [CrossRef]

37. Prasanna, X.; Jafurulla, M.; Sengupta, D.; Chattopadhyay, A. The ganglioside GM1 interacts with the serotonin1A receptor via the sphingolipid binding domain. Biochim. Biophys. Acta. 2016, 1858, 2818-2826. [CrossRef] [PubMed]

38. Schnaar, R.L. Gangliosides of the Vertebrate Nervous System. J. Mol. Biol. 2016, 428, 3325-3336. [CrossRef]

39. Chai, Q.; Arndt, J.W.; Dong, M.; Tepp, W.H.; Johnson, E.A.; Chapman, E.R.; Stevens, R.C. Structural basis of cell surface receptor recognition by botulinum neurotoxin B. Nature 2006, 444, 1096-1100. [CrossRef] [PubMed]

40. Flores, A.; Ramirez-Franco, J.; Desplantes, R.; Debreux, K.; Ferracci, G.; Wernert, F.; Blanchard, M.P.; Maulet, Y.; Youssouf, F.; Sangiardi, M.; et al. Gangliosides interact with synaptotagmin to form the high-affinity receptor complex for botulinum neurotoxin B. Proc. Natl. Acad. Sci. USA 2019, 116, 18098-18108. [CrossRef] [PubMed]

41. Brubaker, S.W.; Bonham, K.S.; Zanoni, I.; Kagan, J.C. Innate immune pattern recognition: A cell biological perspective. Annu. Rev. Immunol. 2015, 33, 257-290. [CrossRef]

42. Medzhitov, R.; Preston-Hurlburt, P.; Janeway, C.A., Jr. A human homologue of the Drosophila Toll protein signals activation of adaptive immunity. Nature 1997, 388, 394-397. [CrossRef]

43. Ciesielska, A.; Matyjek, M.; Kwiatkowska, K. TLR4 and CD14 trafficking and its influence on LPS-induced pro-inflammatory signaling. Cell. Mol. Life Sci. 2021, 78, 1233-1261. [CrossRef] [PubMed]

44. Triantafilou, M.; Miyake, K.; Golenbock, D.T.; Triantafilou, K. Mediators of innate immune recognition of bacteria concentrate in lipid rafts and facilitate lipopolysaccharide-induced cell activation. J. Cell Sci. 2002, 115, 2603-2611. [CrossRef] [PubMed]

45. Ruysschaert, J.M.; Lonez, C. Role of lipid microdomains in TLR-mediated signalling. Biochim. Biophys. Acta 2015, $1848,1860-1867$. [CrossRef] [PubMed]

46. Carroll, R.G.; Zaslona, Z.; Galvan-Pena, S.; Koppe, E.L.; Sevin, D.C.; Angiari, S.; Triantafilou, M.; Triantafilou, K.; Modis, L.K.; O'Neill, L.A. An unexpected link between fatty acid synthase and cholesterol synthesis in proinflammatory macrophage activation. J. Biol. Chem. 2018, 293, 5509-5521. [CrossRef]

47. Mobarak, E.; Haversen, L.; Manna, M.; Rutberg, M.; Levin, M.; Perkins, R.; Rog, T.; Vattulainen, I.; Boren, J. Glucosylceramide modifies the LPS-induced inflammatory response in macrophages and the orientation of the LPS/TLR4 complex in silico. Sci. Rep. 2018, 8, 13600. [CrossRef]

48. Fukuda, Y.; Nakajima, K.; Mutoh, T. Neuroprotection by Neurotropin through Crosstalk of Neurotrophic and Innate Immune Receptors in PC12 Cells. Int. J. Mol. Sci. 2020, 21, 6456. [CrossRef]

49. McNamara, N.; Gallup, M.; Sucher, A.; Maltseva, I.; McKemy, D.; Basbaum, C. AsialoGM1 and TLR5 cooperate in flagellin-induced nucleotide signaling to activate Erk1/2. Am. J. Respir. Cell Mol. Biol. 2006, 34, 653-660. [CrossRef]

50. Liang, S.; Wang, M.; Tapping, R.I.; Stepensky, V.; Nawar, H.F.; Triantafilou, M.; Triantafilou, K.; Connell, T.D.; Hajishengallis, G. Ganglioside GD1a is an essential coreceptor for Toll-like receptor 2 signaling in response to the B subunit of type IIb enterotoxin. J. Biol. Chem. 2007, 282, 7532-7542. [CrossRef]

51. Nakayama, H.; Yoshizaki, F.; Prinetti, A.; Sonnino, S.; Mauri, L.; Takamori, K.; Ogawa, H.; Iwabuchi, K. Lyn-coupled LacCerenriched lipid rafts are required for CD11b/CD18-mediated neutrophil phagocytosis of nonopsonized microorganisms. J. Leukoc. Biol. 2008, 83, 728-741. [CrossRef] [PubMed]

52. Brandel, A.; Aigal, S.; Lagies, S.; Schlimpert, M.; Melendez, A.V.; Xu, M.; Lehmann, A.; Hummel, D.; Fisch, D.; Madl, J.; et al. The Gb3-enriched CD59/flotillin plasma membrane domain regulates host cell invasion by Pseudomonas aeruginosa. Cell. Mol. Life Sci. 2021, 78, 3637-3656. [CrossRef]

53. Jongsma, M.L.M.; de Waard, A.A.; Raaben, M.; Zhang, T.; Cabukusta, B.; Platzer, R.; Blomen, V.A.; Xagara, A.; Verkerk, T.; Bliss, S.; et al. The SPPL3-Defined Glycosphingolipid Repertoire Orchestrates HLA Class I-Mediated Immune Responses. Immunity 2021, 54, 132-150.e139. [CrossRef] [PubMed]

54. Barbat, C.; Trucy, M.; Sorice, M.; Garofalo, T.; Manganelli, V.; Fischer, A.; Mazerolles, F. p56lck, LFA-1 and PI3K but not SHP-2 interact with GM1- or GM3-enriched microdomains in a CD4-p56lck association-dependent manner. Biochem. J. 2007, 402, 471-481. [CrossRef] [PubMed]

55. Nagafuku, M.; Okuyama, K.; Onimaru, Y.; Suzuki, A.; Odagiri, Y.; Yamashita, T.; Iwasaki, K.; Fujiwara, M.; Takayanagi, M.; Ohno, I.; et al. CD4 and CD8 T cells require different membrane gangliosides for activation. Proc. Natl. Acad. Sci. USA 2012, 109, E336-E342. [CrossRef]

56. Minguet, S.; Klasener, K.; Schaffer, A.M.; Fiala, G.J.; Osteso-Ibanez, T.; Raute, K.; Navarro-Lerida, I.; Hartl, F.A.; Seidl, M.; Reth, M.; et al. Caveolin-1-dependent nanoscale organization of the BCR regulates B cell tolerance. Nat. Immunol. 2017, 10, 1150-1159. [CrossRef]

57. Garofalo, T.; Misasi, R.; Mattei, V.; Giammarioli, A.M.; Malorni, W.; Pontieri, G.M.; Pavan, A.; Sorice, M. Association of the death-inducing signaling complex with microdomains after triggering through CD95/Fas. Evidence for caspase-8-ganglioside interaction in T cells. J. Biol. Chem. 2003, 278, 8309-8315. [CrossRef] 
58. Lamers, C.; Pluss, C.J.; Ricklin, D. The Promiscuous Profile of Complement Receptor 3 in Ligand Binding, Immune Modulation, and Pathophysiology. Front. Immunol. 2021, 12, 662164. [CrossRef] [PubMed]

59. Rabb, H.; Michishita, M.; Sharma, C.P.; Brown, D.; Arnaout, M.A. Cytoplasmic tails of human complement receptor type 3 (CR3, $\mathrm{CD11b} / \mathrm{CD} 18$ ) regulate ligand avidity and the internalization of occupied receptors. J. Immunol. 1993, 151, 990-1002.

60. Sato, T.; Iwabuchi, K.; Nagaoka, I.; Adachi, Y.; Ohno, N.; Tamura, H.; Seyama, K.; Fukuchi, Y.; Nakayama, H.; Yoshizaki, F.; et al. Induction of human neutrophil chemotaxis by Candida albicans-derived beta-1,6-long glycoside side-chain-branched beta-glucan. J. Leukoc. Biol. 2006, 80, 204-211. [CrossRef]

61. Chiricozzi, E.; Ciampa, M.G.; Brasile, G.; Compostella, F.; Prinetti, A.; Nakayama, H.; Ekyalongo, R.C.; Iwabuchi, K.; Sonnino, S.; Mauri, L. Direct interaction, instrumental for signaling processes, between LacCer and Lyn in the lipid rafts of neutrophil-like cells. J. Lipid Res. 2015, 56, 129-141. [CrossRef] [PubMed]

62. George, T.; Boyd, B.; Price, M.; Lingwood, C.; Maloney, M. MHC class II proteins contain a potential binding site for the verotoxin receptor glycolipid CD77. Cell. Mol. Biol. 2001, 47, 1179-1185. [PubMed]

63. Jongsma, M.L.M.; Neefjes, J.; Spaapen, R.M. Playing hide and seek: Tumor cells in control of MHC class I antigen presentation. Mol. Immunol. 2021, 136, 36-44. [CrossRef] [PubMed]

64. Nakayama, H.; Nagafuku, M.; Suzuki, A.; Iwabuchi, K.; Inokuchi, J.I. The regulatory roles of glycosphingolipid-enriched lipid rafts in immune systems. FEBS Lett. 2018, 592, 3921-3942. [CrossRef] [PubMed]

65. Ciofani, M.; Zuniga-Pflucker, J.C. The thymus as an inductive site for T lymphopoiesis. Annu. Rev. Cell Dev. Biol. 2007, 23, 463-493. [CrossRef]

66. Heuss, S.F.; Tarantino, N.; Fantini, J.; Ndiaye-Lobry, D.; Moretti, J.; Israel, A.; Logeat, F. A glycosphingolipid binding domain controls trafficking and activity of the mammalian notch ligand delta-like 1. PLoS ONE 2013, 8, e74392. [CrossRef]

67. Sharabi, A.; Tsokos, G.C. T cell metabolism: New insights in systemic lupus erythematosus pathogenesis and therapy. Nat. Rev. Rheumatol. 2020, 16, 100-112. [CrossRef]

68. McDonald, G.; Deepak, S.; Miguel, L.; Hall, C.J.; Isenberg, D.A.; Magee, A.I.; Butters, T.; Jury, E.C. Normalizing glycosphingolipids restores function in CD4+ T cells from lupus patients. J. Clin. Investig. 2014, 124, 712-724. [CrossRef] [PubMed]

69. Kimata, H. GM1, a ganglioside that specifically enhances immunoglobulin production and proliferation in human plasma cells. Eur. J. Immunol. 1994, 24, 2910-2913. [CrossRef]

70. Klasener, K.; Maity, P.C.; Hobeika, E.; Yang, J.; Reth, M. B cell activation involves nanoscale receptor reorganizations and inside-out signaling by Syk. eLife 2014, 3, e02069. [CrossRef]

71. Shrestha, D.; Exley, M.A.; Vereb, G.; Szollosi, J.; Jenei, A. CD1d favors MHC neighborhood, GM1 ganglioside proximity and low detergent sensitive membrane regions on the surface of B lymphocytes. Biochim. Biophys. Acta. 2014, 1840, 667-680. [CrossRef]

72. Schneider, C.; Smith, D.F.; Cummings, R.D.; Boligan, K.F.; Hamilton, R.G.; Bochner, B.S.; Miescher, S.; Simon, H.U.; Pashov, A.; Vassilev, T.; et al. The human IgG anti-carbohydrate repertoire exhibits a universal architecture and contains specificity for microbial attachment sites. Sci. Transl. Med. 2015, 7, 269ra1. [CrossRef]

73. Okuda, T. Application of the Antibody-Inducing Activity of Glycosphingolipids to Human Diseases. Int. J. Mol. Sci. 2021, 22, 3776. [CrossRef] [PubMed]

74. Cutillo, G.; Saariaho, A.H.; Meri, S. Physiology of gangliosides and the role of antiganglioside antibodies in human diseases. Cell. Mol. Immunol. 2020, 17, 313-322. [CrossRef]

75. Ariga, T.; Yu, R.K. Antiglycolipid antibodies in Guillain-Barre syndrome and related diseases: Review of clinical features and antibody specificities. J. Neurosci. Res. 2005, 80, 1-17. [CrossRef] [PubMed]

76. Iwabuchi, K.; Masuda, H.; Kaga, N.; Nakayama, H.; Matsumoto, R.; Iwahara, C.; Yoshizaki, F.; Tamaki, Y.; Kobayashi, T.; Hayakawa, T.; et al. Properties and functions of lactosylceramide from mouse neutrophils. Glycobiology 2015, 25, 655-668. [CrossRef]

77. Okuda, T.; Fukui, A. Generation of anti-oligosaccharide antibodies that recognize mammalian glycoproteins by immunization with a novel artificial glycosphingolipid. Biochem. Biophys. Res. Commun. 2018, 497, 983-989. [CrossRef] [PubMed]

78. Okuda, T.; Shimizu, K.; Hasaba, S.; Date, M. Induction of specific adaptive immune responses by immunization with newly designed artificial glycosphingolipids. Sci. Rep. 2019, 9, 18803. [CrossRef]

79. Shima, S.; Kawamura, N.; Ishikawa, T.; Masuda, H.; Iwahara, C.; Niimi, Y.; Ueda, A.; Iwabuchi, K.; Mutoh, T. Anti-neutral glycolipid antibodies in encephalomyeloradiculoneuropathy. Neurology. 2014, 82, 114-118. [CrossRef]

80. Gajate, C.; Del Canto-Jañez, E.; Acuña, A.U.; Amat-Guerri, F.; Geijo, E.; Santos-Beneit, A.M.; Veldman, R.J.; Mollinedo, F. Intracellular triggering of Fas aggregation and recruitment of apoptotic molecules into Fas-enriched rafts in selective tumor cell apoptosis. J. Exp. Med. 2004, 200, 353-365. [CrossRef]

81. Elmore, S. Apoptosis: A review of programmed cell death. Toxicol. Pathol. 2007, 35, 495-516. [CrossRef]

82. Gajate, C.; Gonzalez-Camacho, F.; Mollinedo, F. Involvement of raft aggregates enriched in Fas/CD95 death-inducing signaling complex in the antileukemic action of edelfosine in Jurkat cells. PLoS ONE 2009, 4, e5044. [CrossRef] [PubMed]

83. Nikoletopoulou, V.; Markaki, M.; Palikaras, K.; Tavernarakis, N. Crosstalk between apoptosis, necrosis and autophagy. Biochim. Biophys. Acta 2013, 1833, 3448-3459. [CrossRef]

84. Mollinedo, F.; Gajate, C. Lipid rafts as signaling hubs in cancer cell survival/death and invasion: Implications in tumor progression and therapy: Thematic Review Series: Biology of Lipid Rafts. J. Lipid Res. 2020, 61, 611-635. [CrossRef] [PubMed] 
85. Mollinedo, F.; Gajate, C. Lipid rafts, death receptors and CASMERs: New insights for cancer therapy. Future Oncol. 2010, 6, 491-494. [CrossRef]

86. Mollinedo, F.; Gajate, C. Lipid rafts and clusters of apoptotic signaling molecule-enriched rafts in cancer therapy. Future Oncol. 2010, 6, 811-821. [CrossRef]

87. Kiguchi, K.; Henning-Chubb, C.B.; Huberman, E. Glycosphingolipid patterns of peripheral blood lymphocytes, monocytes, and granulocytes are cell specific. J. Biochem. 1990, 107, 8-14. [CrossRef]

88. Malorni, W.; Giammarioli, A.M.; Garofalo, T.; Sorice, M. Dynamics of lipid raft components during lymphocyte apoptosis: The paradigmatic role of GD3. Apoptosis 2007, 12, 941-949. [CrossRef]

89. Malisan, F.; Testi, R. GD3 ganglioside and apoptosis. Biochim. Biophys. Acta 2002, 1585, 179-187. [CrossRef]

90. Scorrano, L.; Petronilli, V.; Di Lisa, F.; Bernardi, P. Commitment to apoptosis by GD3 ganglioside depends on opening of the mitochondrial permeability transition pore. J. Biol. Chem. 1999, 274, 22581-22585. [CrossRef] [PubMed]

91. Rippo, M.R.; Malisan, F.; Ravagnan, L.; Tomassini, B.; Condo, I.; Costantini, P.; Susin, S.A.; Rufini, A.; Todaro, M.; Kroemer, G.; et al. GD3 ganglioside directly targets mitochondria in a bcl-2-controlled fashion. FASEB J. 2000, 14, 2047-2054. [CrossRef]

92. Garcia-Ruiz, C.; Colell, A.; Morales, A.; Calvo, M.; Enrich, C.; Fernandez-Checa, J.C. Trafficking of ganglioside GD3 to mitochondria by tumor necrosis factor-alpha. J. Biol. Chem. 2002, 277, 36443-36448. [CrossRef] [PubMed]

93. Garofalo, T.; Giammarioli, A.M.; Misasi, R.; Tinari, A.; Manganelli, V.; Gambardella, L.; Pavan, A.; Malorni, W.; Sorice, M. Lipid microdomains contribute to apoptosis-associated modifications of mitochondria in T cells. Cell Death Differ. 2005, 12, 1378-1389. [CrossRef]

94. Takeuchi, R.; Kambe, M.; Miyata, M.; Jeyadevan, U.; Tajima, O.; Furukawa, K.; Furukawa, K. TNF $\alpha$-signal and cAMP-mediated signals oppositely regulate melanoma- associated ganglioside GD3 synthase gene in human melanocytes. Sci. Rep. 2019, 9, 14740. [CrossRef] [PubMed]

95. Kina, K.; Masuda, H.; Nakayama, H.; Nagatsuka, Y.; Nabetani, T.; Hirabayashi, Y.; Takahashi, Y.; Shimada, K.; Daida, H.; Ogawa, H.; et al. The novel neutrophil differentiation marker phosphatidylglucoside mediates neutrophil apoptosis. J. Immunol. 2011, 186, 5323-5332. [CrossRef] [PubMed]

96. Murate, M.; Hayakawa, T.; Ishii, K.; Inadome, H.; Greimel, P.; Watanabe, M.; Nagatsuka, Y.; Ito, K.; Ito, Y.; Takahashi, H.; et al. Phosphatidylglucoside forms specific lipid domains on the outer leaflet of the plasma membrane. Biochemistry 2010, 49, 4732-4739. [CrossRef] [PubMed]

97. Oka, S.; Nagatsuka, Y.; Kikuchi, J.; Yokote, T.; Hirabayashi, Y.; Hanafusa, T.; Ozawa, K.; Muroi, K. Preferential expression of phosphatidylglucoside along neutrophil differentiation pathway. Leuk. Lymphoma 2009, 50, 1190-1197. [CrossRef] [PubMed]

98. Nagatsuka, Y.; Hara-Yokoyama, M.; Kasama, T.; Takekoshi, M.; Maeda, F.; Ihara, S.; Fujiwara, S.; Ohshima, E.; Ishii, K.; Kobayashi, T.; et al. Carbohydrate-dependent signaling from the phosphatidylglucoside-based microdomain induces granulocytic differentiation of HL60 cells. Proc. Natl. Acad. Sci. USA 2003, 100, 7454-7459. [CrossRef] [PubMed]

99. Booth, L.A.; Tavallai, S.; Hamed, H.A.; Cruickshanks, N.; Dent, P. The role of cell signalling in the crosstalk between autophagy and apoptosis. Cell. Signal. 2014, 26, 549-555. [CrossRef]

100. Delgado, M.E.; Dyck, L.; Laussmann, M.A.; Rehm, M. Modulation of apoptosis sensitivity through the interplay with autophagic and proteasomal degradation pathways. Cell Death Dis. 2014, 5, e1011. [CrossRef]

101. Cuervo, A.M. Autophagy: In sickness and in health. Trends Cell Biol. 2004, 14, 70-77. [CrossRef]

102. D'Arcy, M.S. Cell death: A review of the major forms of apoptosis, necrosis and autophagy. Cell Biol. Int. 2019, 43, 582-592. [CrossRef]

103. Levy, J.M.M.; Towers, C.G.; Thorburn, A. Targeting autophagy in cancer. Nat. Rev. Cancer 2017, 17, 528-542. [CrossRef] [PubMed]

104. Matarrese, P.; Garofalo, T.; Manganelli, V.; Gambardella, L.; Marconi, M.; Grasso, M.; Tinari, A.; Misasi, R.; Malorni, W.; Sorice, M. Evidence for the involvement of GD3 ganglioside in autophagosome formation and maturation. Autophagy 2014, 10, 750-765. [CrossRef] [PubMed]

105. Hamasaki, M.; Furuta, N.; Matsuda, A.; Nezu, A.; Yamamoto, A.; Fujita, N.; Oomori, H.; Noda, T.; Haraguchi, T.; Hiraoka, Y.; et al. Autophagosomes form at ER-mitochondria contact sites. Nature 2013, 495, 389-393. [CrossRef] [PubMed]

106. Garofalo, T.; Matarrese, P.; Manganelli, V.; Marconi, M.; Tinari, A.; Gambardella, L.; Faggioni, A.; Misasi, R.; Sorice, M.; Malorni, W. Evidence for the involvement of lipid rafts localized at the ER-mitochondria associated membranes in autophagosome formation. Autophagy 2016, 12, 917-935. [CrossRef]

107. Molino, D.; Nascimbeni, A.C.; Giordano, F.; Codogno, P.; Morel, E. ER-driven membrane contact sites: Evolutionary conserved machineries for stress response and autophagy regulation? Commun. Integr. Biol. 2017, 10, e1401699. [CrossRef]

108. Nascimbeni, A.C.; Giordano, F.; Dupont, N.; Grasso, D.; Vaccaro, M.I.; Codogno, P.; Morel, E. ER-plasma membrane contact sites contribute to autophagosome biogenesis by regulation of local PI3P synthesis. EMBO J. 2017, 36, 2018-2033. [CrossRef] [PubMed]

109. Xu, Y.; Eissa, N.T. Autophagy in innate and adaptive immunity. Proc. Am. Thorac. Soc. 2010, 7, 22-28. [CrossRef] [PubMed]

110. Shen, W.; Stone, K.; Jales, A.; Leitenberg, D.; Ladisch, S. Inhibition of TLR activation and up-regulation of IL-1R-associated kinase-M expression by exogenous gangliosides. J. Immunol. 2008, 180, 4425-4432. [CrossRef] [PubMed]

111. Nikolaeva, S.; Bayunova, L.; Sokolova, T.; Vlasova, Y.; Bachteeva, V.; Avrova, N.; Parnova, R. GM1 and GD1a gangliosides modulate toxic and inflammatory effects of E. coli lipopolysaccharide by preventing TLR4 translocation into lipid rafts. Biochim. Biophys. Acta 2015, 1851, 239-247. [CrossRef] [PubMed] 
112. Kim, H.S.; Han, M.; Park, I.H.; Park, C.H.; Kwak, M.S.; Shin, J.S. Sulfatide Inhibits HMGB1 Secretion by Hindering Toll-Like Receptor 4 Localization Within Lipid Rafts. Front. Immunol. 2020, 11, 1305. [CrossRef] [PubMed]

113. Kondo, Y.; Ikeda, K.; Tokuda, N.; Nishitani, C.; Ohto, U.; Akashi-Takamura, S.; Ito, Y.; Uchikawa, M.; Kuroki, Y.; Taguchi, R.; et al. TLR4-MD-2 complex is negatively regulated by an endogenous ligand, globotetraosylceramide. Proc. Natl. Acad. Sci. USA 2013, 110, 4714-4719. [CrossRef] [PubMed]

114. Nitta, T.; Kanoh, H.; Inamori, K.I.; Suzuki, A.; Takahashi, T.; Inokuchi, J.I. Globo-series glycosphingolipids enhance Toll-like receptor 4-mediated inflammation and play a pathophysiological role in diabetic nephropathy. Glycobiology 2019, 29, 260-268. [CrossRef] [PubMed]

115. Kanoh, H.; Nitta, T.; Go, S.; Inamori, K.I.; Veillon, L.; Nihei, W.; Fujii, M.; Kabayama, K.; Shimoyama, A.; Fukase, K.; et al. Homeostatic and pathogenic roles of GM3 ganglioside molecular species in TLR4 signaling in obesity. EMBO J. 2020, 39 , e101732. [CrossRef]

116. Su, L.; Athamna, M.; Wang, Y.; Wang, J.; Freudenberg, M.; Yue, T.; Wang, J.; Moresco, E.M.Y.; He, H.; Zor, T.; et al. Sulfatides are endogenous ligands for the TLR4-MD-2 complex. Proc. Natl. Acad. Sci. USA 2021, 118, e2105316118. [CrossRef] [PubMed]

117. Nagata, M.; Izumi, Y.; Ishikawa, E.; Kiyotake, R.; Doi, R.; Iwai, S.; Omahdi, Z.; Yamaji, T.; Miyamoto, T.; Bamba, T.; et al. Intracellular metabolite beta-glucosylceramide is an endogenous Mincle ligand possessing immunostimulatory activity. Proc. Natl. Acad. Sci. USA 2017, 114, E3285-E3294. [CrossRef]

118. Okubo, K.; Brenner, M.D.; Cullere, X.; Saggu, G.; Patchen, M.L.; Bose, N.; Mihori, S.; Yuan, Z.; Lowell, C.A.; Zhu, C.; et al Inhibitory affinity modulation of FcgammaRIIA ligand binding by glycosphingolipids by inside-out signaling. Cell Rep. 2021, 35, 109142. [CrossRef]

119. Jales, A.; Falahati, R.; Mari, E.; Stemmy, E.J.; Shen, W.; Southammakosane, C.; Herzog, D.; Ladisch, S.; Leitenberg, D. Gangliosideexposed dendritic cells inhibit T-cell effector function by promoting regulatory cell activity. Immunology 2011, 132, 134-143. [CrossRef]

120. Lee, H.C.; Wondimu, A.; Liu, Y.; Ma, J.S.; Radoja, S.; Ladisch, S. Ganglioside inhibition of CD8+ T cell cytotoxicity: Interference with lytic granule trafficking and exocytosis. J. Immunol. 2012, 189, 3521-3527. [CrossRef]

121. Dillinger, B.; Ahmadi-Erber, S.; Lau, M.; Hoelzl, M.A.; Erhart, F.; Juergens, B.; Fuchs, D.; Heitger, A.; Ladisch, S.; Dohnal, A.M IFN-gamma and tumor gangliosides: Implications for the tumor microenvironment. Cell. Immunol. 2018, 325, 33-40. [CrossRef]

122. Kanda, N.; Tamaki, K. Ganglioside GQ1b enhances Ig production by human PBMCs. J. Allergy Clin. Immunol. 1998, 102, 813-820. [CrossRef]

123. Chatterjee, S.; Balram, A.; Li, W. Convergence: Lactosylceramide-Centric Signaling Pathways Induce Inflammation, Oxidative Stress, and Other Phenotypic Outcomes. Int. J. Mol. Sci. 2021, 22, 1816. [CrossRef] [PubMed]

124. Chatterjee, S. Sphingolipids in atherosclerosis and vascular biology. Arterioscler. Thromb. Vasc. Biol. 1998, 18, 1523-1533. [CrossRef]

125. Arai, T.; Bhunia, A.K.; Chatterjee, S.; Bulkley, G.B. Lactosylceramide stimulates human neutrophils to upregulate Mac-1, adhere to endothelium, and generate reactive oxygen metabolites in vitro. Circ. Res. 1998, 82, 540-547. [CrossRef] [PubMed]

126. Poulain, D.; Jouault, T. Candida albicans cell wall glycans, host receptors and responses: Elements for a decisive crosstalk. Curr. Opin. Microbiol. 2004, 7, 342-349. [CrossRef]

127. Kumar, A.; Suryadevara, N.; Hill, T.M.; Bezbradica, J.S.; Van Kaer, L.; Joyce, S. Natural Killer T Cells: An Ecological Evolutionary Developmental Biology Perspective. Front. Immunol. 2017, 8, 1858. [CrossRef]

128. Kawano, T.; Cui, J.; Koezuka, Y.; Toura, I.; Kaneko, Y.; Sato, H.; Kondo, E.; Harada, M.; Koseki, H.; Nakayama, T.; et al. Natural killer-like nonspecific tumor cell lysis mediated by specific ligand-activated Valpha14 NKT cells. Proc. Natl. Acad. Sci. USA 1998, 95, 5690-5693. [CrossRef]

129. Rossjohn, J.; Pellicci, D.G.; Patel, O.; Gapin, L.; Godfrey, D.I. Recognition of CD1d-restricted antigens by natural killer T cells. Nat. Rev. Immunol. 2012, 12, 845-857. [CrossRef]

130. Kain, L.; Webb, B.; Anderson, B.L.; Deng, S.; Holt, M.; Costanzo, A.; Zhao, M.; Self, K.; Teyton, A.; Everett, C.; et al. The identification of the endogenous ligands of natural killer $\mathrm{T}$ cells reveals the presence of mammalian alpha-linked glycosylceramides. Immunity 2014, 41, 543-554. [CrossRef] [PubMed]

131. Tsai, B.; Gilbert, J.M.; Stehle, T.; Lencer, W.; Benjamin, T.L.; Rapoport, T.A. Gangliosides are receptors for murine polyoma virus and SV40. EMBO J. 2003, 22, 4346-4355. [CrossRef]

132. Fantini, J.; Di Scala, C.; Chahinian, H.; Yahi, N. Structural and molecular modelling studies reveal a new mechanism of action of chloroquine and hydroxychloroquine against SARS-CoV-2 infection. Int. J. Antimicrob. Agents 2020, 55, 105960. [CrossRef]

133. Fantini, J.; Chahinian, H.; Yahi, N. Leveraging coronavirus binding to gangliosides for innovative vaccine and therapeutic strategies against COVID-19. Biochem. Biophys. Res. Commun. 2021, 538, 132-136.

134. Sorice, M.; Misasi, R.; Riitano, G.; Manganelli, V.; Martellucci, S.; Longo, A.; Garofalo, T.; Mattei, V. Targeting Lipid Rafts as a Strategy Against Coronavirus. Front. Cell Dev. Biol. 2020, 8, 618296. [CrossRef] [PubMed]

135. Lingwood, C.A. Role of verotoxin receptors in pathogenesis. Trends Microbiol. 1996, 4, 147-153. [CrossRef]

136. Louise, C.B.; Kaye, S.A.; Boyd, B.; Lingwood, C.A.; Obrig, T.G. Shiga toxin-associated hemolytic uremic syndrome: Effect of sodium butyrate on sensitivity of human umbilical vein endothelial cells to Shiga toxin. Infect. Immun. 1995, 63, 2766-2769. [CrossRef] 
137. Takenouchi, H.; Kiyokawa, N.; Taguchi, T.; Matsui, J.; Katagiri, Y.U.; Okita, H.; Okuda, K.; Fujimoto, J. Shiga toxin binding to globotriaosyl ceramide induces intracellular signals that mediate cytoskeleton remodeling in human renal carcinoma-derived cells. J. Cell Sci. 2004, 117, 3911-3922. [CrossRef] [PubMed]

138. Tyrrell, G.J.; Ramotar, K.; Toye, B.; Boyd, B.; Lingwood, C.A.; Brunton, J.L. Alteration of the carbohydrate binding specificity of verotoxins from Gal alpha 1-4Gal to GalNAc beta 1-3Gal alpha 1-4Gal and vice versa by site-directed mutagenesis of the binding subunit. Proc. Natl. Acad. Sci. USA 1992, 89, 524-528. [CrossRef]

139. Legros, N.; Dusny, S.; Humpf, H.U.; Pohlentz, G.; Karch, H.; Muthing, J. Shiga toxin glycosphingolipid receptors and their lipid membrane ensemble in primary human blood-brain barrier endothelial cells. Glycobiology 2017, 27, 99-109. [CrossRef] [PubMed]

140. Legros, N.; Pohlentz, G.; Steil, D.; Muthing, J. Shiga toxin-glycosphingolipid interaction: Status quo of research with focus on primary human brain and kidney endothelial cells. Int. J. Med. Microbiol. 2018, 308, 1073-1084. [CrossRef] [PubMed]

141. Detzner, J.; Krojnewski, E.; Pohlentz, G.; Steil, D.; Humpf, H.U.; Mellmann, A.; Karch, H.; Müthing, J. Shiga Toxin (Stx)-Binding Glycosphingolipids of Primary Human Renal Cortical Epithelial Cells (pHRCEpiCs) and Stx-Mediated Cytotoxicity. Toxins 2021, 13, 139. [CrossRef] [PubMed]

142. Lee, M.S.; Koo, S.; Jeong, D.G.; Tesh, V.L. Shiga Toxins as Multi-Functional Proteins: Induction of Host Cellular Stress Responses, Role in Pathogenesis and Therapeutic Applications. Toxins 2016, 8, 77. [CrossRef] [PubMed]

143. Lee, M.S.; Tesh, V.L. Roles of Shiga Toxins in Immunopathology. Toxins 2019, 11, 212. [CrossRef] [PubMed]

144. Bieri, J.; Leisi, R.; Bircher, C.; Ros, C. Human parvovirus B19 interacts with globoside under acidic conditions as an essential step in endocytic trafficking. PLoS Pathog. 2021, 17, e1009434. [CrossRef] [PubMed]

145. Madar Johansson, M.; Belurier, E.; Papageorgiou, A.C.; Sundin, A.P.; Rahkila, J.; Kallonen, T.; Nilsson, U.J.; Maatsola, S.; Nyholm, T.K.M.; Kapyla, J.; et al. The binding mechanism of the virulence factor Streptococcus suis adhesin P subtype to globotetraosylceramide is associated with systemic disease. J. Biol. Chem. 2020, 295, 14305-14324. [CrossRef]

146. Mukai, T.; Kaneko, S.; Matsumoto, M.; Ohori, H. Binding of Bifidobacterium bifidum and Lactobacillus reuteri to the carbohydrate moieties of intestinal glycolipids recognized by peanut agglutinin. Int. J. Food Microbiol. 2004, 90, 357-362. [CrossRef]

147. De Bentzmann, S.; Roger, P.; Dupuit, F.; Bajolet-Laudinat, O.; Fuchey, C.; Plotkowski, M.C.; Puchelle, E. Asialo GM1 is a receptor for Pseudomonas aeruginosa adherence to regenerating respiratory epithelial cells. Infect. Immun. 1996, 64, 1582-1588. [CrossRef] [PubMed]

148. Naroeni, A.; Porte, F. Role of cholesterol and the ganglioside GM(1) in entry and short-term survival of Brucella suis in murine macrophages. Infect. Immun. 2002, 70, 1640-1644. [CrossRef]

149. Cuatrecasas, P. Vibrio cholerae choleragenoid. Mechanism of inhibition of cholera toxin action. Biochemistry 1973, 12, 3577-3581. [CrossRef]

150. Cuatrecasas, P. Gangliosides and membrane receptors for cholera toxin. Biochemistry 1973, 12, 3558-3566. [CrossRef]

151. Hyun, C.S.; Kimmich, G.A. Interaction of cholera toxin and Escherichia coli enterotoxin with isolated intestinal epithelial cells. Am. J. Physiol. 1984, 247, G623-G631. [CrossRef]

152. Ewers, H.; Römer, W.; Smith, A.E.; Bacia, K.; Dmitrieff, S.; Chai, W.; Mancini, R.; Kartenbeck, J.; Chambon, V.; Berland, L.; et al. GM1 structure determines SV40-induced membrane invagination and infection. Nat. Cell Biol. 2010, 1, 11-18. [CrossRef]

153. Saslowsky, D.E.; Te Welscher, Y.M.; Chinnapen, D.J.; Wagner, J.S.; Wan, J.; Kern, E.; Lencer, W.I. Ganglioside GM1-mediated transcytosis of cholera toxin bypasses the retrograde pathway and depends on the structure of the ceramide domain. J. Biol. Chem. 2013, 288, 25804-25809. [CrossRef] [PubMed]

154. Kabbani, A.M.; Raghunathan, K.; Lencer, W.I.; Kenworthy, A.K.; Kelly, C.V. Structured clustering of the glycosphingolipid GM1 is required for membrane curvature induced by cholera toxin. Proc. Natl. Acad. Sci. USA 2020, 117, 14978-14986. [CrossRef]

155. Kuziemko, G.M.; Stroh, M.; Stevens, R.C. Cholera toxin binding affinity and specificity for gangliosides determined by surface plasmon resonance. Biochemistry 1996, 35, 6375-6384. [CrossRef]

156. Masserini, M.; Freire, E.; Palestini, P.; Calappi, E.; Tettamanti, G. Fuc-GM1 ganglioside mimics the receptor function of GM1 for cholera toxin. Biochemistry 1992, 31, 2422-2426. [CrossRef]

157. Suzuki, T.; Sometani, A.; Yamazaki, Y.; Horiike, G.; Mizutani, Y.; Masuda, H.; Yamada, M.; Tahara, H.; Xu, G.; Miyamoto, D.; et al. Sulphatide binds to human and animal influenza A viruses, and inhibits the viral infection. Biochem. J. 1996, 318, 389-393. [CrossRef]

158. Bally, M.; Rydell, G.E.; Zahn, R.; Nasir, W.; Eggeling, C.; Breimer, M.E.; Svensson, L.; Hook, F.; Larson, G. Norovirus GII.4 virus-like particles recognize galactosylceramides in domains of planar supported lipid bilayers. Angew. Chem. Int. Ed. Engl. 2012, 51, 12020-12024. [CrossRef] [PubMed]

159. Beckmann, N.; Becker, K.A. Ceramide and Related Molecules in Viral Infections. Int. J. Mol. Sci. 2021, $22,5676$.

160. Fantini, J.; Hammache, D.; Pieroni, G.; Yahi, N. Role of glycosphingolipid microdomains in CD4-dependent HIV-1 fusion. Glycoconj. J. 2000, 17, 199-204. [CrossRef] [PubMed]

161. Popik, W.; Alce, T.M.; Au, W.C. Human immunodeficiency virus type 1 uses lipid raft-colocalized CD4 and chemokine receptors for productive entry into CD4(+) T cells. J. Virol. 2002, 76, 4709-4722. [CrossRef] [PubMed]

162. Kamiyama, H.; Yoshii, H.; Tanaka, Y.; Sato, H.; Yamamoto, N.; Kubo, Y. Raft localization of CXCR4 is primarily required for X4-tropic human immunodeficiency virus type 1 infection. Virology 2009, 386, 23-31. [CrossRef] [PubMed]

163. Hanafusa, K.; Hotta, T.; Iwabuchi, K. Glycolipids: Linchpins in the Organization and Function of Membrane Microdomains. Front. Cell Dev. Biol. 2020, 8, 589799. [CrossRef] 
164. Oishi, K.; Morise, M.; Vo, L.K.; Tran, N.T.; Sahashi, D.; Ueda-Wakamatsu, R.; Nishimura, W.; Komatsu, M.; Shiozaki, K. Host lactosylceramide enhances Edwardsiella tarda infection. Cell. Microbiol. 2021, 9, e13365.

165. Newburg, D.S.; Chaturvedi, P. Neutral glycolipids of human and bovine milk. Lipids 1992, 27, 923-927. [CrossRef]

166. Ohno, N.; Uchiyama, M.; Tsuzuki, A.; Tokunaka, K.; Miura, N.N.; Adachi, Y.; Aizawa, M.W.; Tamura, H.; Tanaka, S.; Yadomae, T. Solubilization of yeast cell-wall beta-(1->3)-D-glucan by sodium hypochlorite oxidation and dimethyl sulfoxide extraction Carbohydr. Res. 1999, 316, 161-172. [CrossRef]

167. Zimmerman, J.W.; Lindermuth, J.; Fish, P.A.; Palace, G.P.; Stevenson, T.T.; DeMong, D.E. A novel carbohydrate-glycosphingolipid interaction between a beta-(1-3)-glucan immunomodulator, PGG-glucan, and lactosylceramide of human leukocytes. J. Biol. Chem. 1998, 273, 22014-22020. [CrossRef] [PubMed]

168. Brown, G.D.; Gordon, S. Immune recognition. A new receptor for beta-glucans. Nature 2001, 413, 36-37. [CrossRef]

169. Briken, V.; Porcelli, S.A.; Besra, G.S.; Kremer, L. Mycobacterial lipoarabinomannan and related lipoglycans: From biogenesis to modulation of the immune response. Mol. Microbiol. 2004, 53, 391-403. [CrossRef]

170. Mishra, A.K.; Driessen, N.N.; Appelmelk, B.J.; Besra, G.S. Lipoarabinomannan and related glycoconjugates: Structure, biogenesis and role in Mycobacterium tuberculosis physiology and host-pathogen interaction. FEMS Microbiol. Rev. 2011, 35, 1126-1157. [CrossRef] [PubMed]

171. Kaur, D.; Obregon-Henao, A.; Pham, H.; Chatterjee, D.; Brennan, P.J.; Jackson, M. Lipoarabinomannan of Mycobacterium: Mannose capping by a multifunctional terminal mannosyltransferase. Proc. Natl. Acad. Sci. USA 2008, 105, 17973-17977. [CrossRef]

172. Belotserkovsky, I.; Brunner, K.; Pinaud, L.; Rouvinski, A.; Dellarole, M.; Baron, B.; Dubey, G.; Samassa, F.; Parsot, C.; Sansonetti, P.; et al. Glycan-Glycan Interaction Determines Shigella Tropism toward Human T Lymphocytes. mBio 2018, 9, e02309-17. [CrossRef]

173. Haney, M.S.; Bohlen, C.J.; Morgens, D.W.; Ousey, J.A.; Barkal, A.A.; Tsui, C.K.; Ego, B.K.; Levin, R.; Kamber, R.A.; Collins, H.; et al. Identification of phagocytosis regulators using magnetic genome-wide CRISPR screens. Nat. Genet. 2018, 50, 1716-1727. [CrossRef] [PubMed]

174. Niekamp, P.; Guzman, G.; Leier, H.C.; Rashidfarrokhi, A.; Richina, V.; Pott, F.; Barisch, C.; Holthuis, J.C.M.; Tafesse, F.G. Sphingomyelin Biosynthesis Is Essential for Phagocytic Signaling during Mycobacterium tuberculosis Host Cell Entry. mBio 2021, 12, e03141-20. [CrossRef] [PubMed]

175. Pathak, D.; Mehendale, N.; Singh, S.; Mallik, R.; Kamat, S.S. Lipidomics Suggests a New Role for Ceramide Synthase in Phagocytosis. ACS Chem. Biol. 2018, 13, 2280-2287. [CrossRef]

176. Ellison, C.J.; Kukulski, W.; Boyle, K.B.; Munro, S.; Randow, F. Transbilayer Movement of Sphingomyelin Precedes Catastrophic Breakage of Enterobacteria-Containing Vacuoles. Curr. Biol. 2020, 30, 2974-2983.e2976. [CrossRef] [PubMed]

177. Thurston, T.L.; Wandel, M.P.; von Muhlinen, N.; Foeglein, A.; Randow, F. Galectin 8 targets damaged vesicles for autophagy to defend cells against bacterial invasion. Nature 2012, 482, 414-418. [CrossRef]

178. Niekamp, P.; Sokoya, T.; Vittadello, L.; Deng, Y.; Kim, Y.; Hilderink, A.; Imlau, M.; Clarke, C.J.; Burd, C.G.; Holthuis, J.C.M $\mathrm{Ca}^{2+}$-activated sphingomyelin scrambling and turnover mediate ESCRT-independent lysosomal repair. bioRxiv 2021. [CrossRef]

179. Bussi, C.; Gutierrez, M.G. Mycobacterium tuberculosis infection of host cells in space and time. FEMS Microbiol. Rev. 2019, 43, 341-361. [CrossRef]

180. Wang, K.; Wang, J.; Sun, T.; Bian, G.; Pan, W.; Feng, T.; Wang, P.; Li, Y.; Dai, J. Glycosphingolipid GM3 is Indispensable for Dengue Virus Genome Replication. Int. J. Biol. Sci. 2016, 12, 872-883. [CrossRef]

181. Yager, E.J.; Konan, K.V. Sphingolipids as Potential Therapeutic Targets against Enveloped Human RNA Viruses. Viruses 2019, 11, 912. [CrossRef]

182. Dirlikov, E.; Torres, J.V.; Martines, R.B.; Reagan-Steiner, S.; Perez, G.V.; Rivera, A.; Major, C.; Matos, D.; Munoz-Jordan, J.; Shieh, W.J.; et al. Postmortem Findings in Patient with Guillain-Barre Syndrome and Zika Virus Infection. Emerg. Infect. Dis. 2018, 24, 114-117. [CrossRef]

183. Cao-Lormeau, V.-M.; Blake, A.; Mons, S.; Lastère, S.; Roche, C.; Vanhomwegen, J.; Dub, T.; Baudouin, L.; Teissier, A.; Larre, P.; et al. Guillain-Barré Syndrome outbreak associated with Zika virus infection in French Polynesia: A case-control study. Lancet 2016, 387, 1531-1539. [CrossRef]

184. Rivera-Correa, J.; de Siqueira, I.C.; Mota, S.; do Rosario, M.S.; Pereira de Jesus, P.A.; Alcantara, L.C.J.; Ernst, J.D.; Rodriguez, A. Anti-ganglioside antibodies in patients with Zika virus infection-associated Guillain-Barre Syndrome in Brazil. PLoS Negl. Trop. Dis. 2019, 13, e0007695. [CrossRef]

185. Leier, H.C.; Weinstein, J.B.; Kyle, J.E.; Lee, J.Y.; Bramer, L.M.; Stratton, K.G.; Kempthorne, D.; Navratil, A.R.; Tafesse, E.G.; Hornemann, T.; et al. A global lipid map defines a network essential for Zika virus replication. Nat. Commun. 2020, 11, 3652. [CrossRef]

186. Plante, J.A.; Liu, Y.; Liu, J.; Xia, H.; Johnson, B.A.; Lokugamage, K.G.; Zhang, X.; Muruato, A.E.; Zou, J.; Fontes-Garfias, C.R.; et al. Spike mutation D614G alters SARS-CoV-2 fitness. Nature 2021, 592, 116-121. [CrossRef] [PubMed]

187. Marfia, G.; Navone, S.; Guarnaccia, L.; Campanella, R.; Mondoni, M.; Locatelli, M.; Barassi, A.; Fontana, L.; Palumbo, F.; Garzia, E.; et al. Decreased serum level of sphingosine-1-phosphate: A novel predictor of clinical severity in COVID-19. EMBO Mol. Med. 2021, 13, e13424. [CrossRef] [PubMed]

188. Rosen, H.; Oldstone, M.B.A. The riddle of the Sphinx: Why sphingosine-1-phosphate may help define molecular mechanisms underlying risk stratification for serious COVID-19 infections. EMBO Mol. Med. 2021, 13, e13533. [CrossRef] 
189. Zhang, Y.; Li, X.; Carpinteiro, A.; Gulbins, E. Acid sphingomyelinase amplifies redox signaling in Pseudomonas aeruginosainduced macrophage apoptosis. J. Immunol. 2008, 181, 4247-4254. [CrossRef] [PubMed]

190. Kita, K.; Okino, N.; Ito, M. Reverse hydrolysis reaction of a recombinant alkaline ceramidase of Pseudomonas aeruginosa. Biochim. Biophys. Acta 2000, 1485, 111-120. [CrossRef]

191. Luberto, C.; Stonehouse, M.J.; Collins, E.A.; Marchesini, N.; El-Bawab, S.; Vasil, A.I.; Vasil, M.L.; Hannun, Y.A. Purification, characterization, and identification of a sphingomyelin synthase from Pseudomonas aeruginosa. PlcH is a multifunctional enzyme. J. Biol. Chem. 2003, 278, 32733-32743. [CrossRef]

192. Okino, N.; Ito, M. Ceramidase enhances phospholipase C-induced hemolysis by Pseudomonas aeruginosa. J. Biol. Chem. 2007, 282, 6021-6030. [CrossRef]

193. Koch-Edelmann, S.; Banhart, S.; Saied, E.M.; Rose, L.; Aeberhard, L.; Laue, M.; Doellinger, J.; Arenz, C.; Heuer, D. The cellular ceramide transport protein CERT promotes Chlamydia psittaci infection and controls bacterial sphingolipid uptake. Cell. Microbiol. 2017, 19, e12752. [CrossRef]

194. Banhart, S.; Schafer, E.K.; Gensch, J.M.; Heuer, D. Sphingolipid Metabolism and Transport in Chlamydia trachomatis and Chlamydia psittaci Infections. Front. Cell Dev. Biol. 2019, 7, 223. [CrossRef]

195. Elwell, C.A.; Jiang, S.; Kim, J.H.; Lee, A.; Wittmann, T.; Hanada, K.; Melancon, P.; Engel, J.N. Chlamydia trachomatis co-opts GBF1 and CERT to acquire host sphingomyelin for distinct roles during intracellular development. PLoS Pathog. 2011, 7, e1002198. [CrossRef]

196. Tachida, Y.; Kumagai, K.; Sakai, S.; Ando, S.; Yamaji, T.; Hanada, K. Chlamydia trachomatis-infected human cells convert ceramide to sphingomyelin without sphingomyelin synthases 1 and 2. FEBS Lett. 2020, 594, 519-529. [CrossRef] [PubMed]

197. Capmany, A.; Gambarte Tudela, J.; Alonso Bivou, M.; Damiani, M.T. Akt/AS160 Signaling Pathway Inhibition Impairs Infection by Decreasing Rab14-Controlled Sphingolipids Delivery to Chlamydial Inclusions. Front. Microbiol. 2019, 10, 666. [CrossRef]

198. Hotinger, J.A.; May, A.E. Antibodies Inhibiting the Type III Secretion System of Gram-Negative Pathogenic Bacteria. Antibodies 2020, 9, 35. [CrossRef] [PubMed]

199. Coburn, B.; Sekirov, I.; Finlay, B.B. Type III secretion systems and disease. Clin. Microbiol. Rev. 2007, 20, 535-549. [CrossRef] [PubMed]

200. Bah, A.; Sanicas, M.; Nigou, J.; Guilhot, C.; Astarie-Dequeker, C.; Vergne, I. The Lipid Virulence Factors of Mycobacterium tuberculosis Exert Multilayered Control over Autophagy-Related Pathways in Infected Human Macrophages. Cells 2020, 9, 666. [CrossRef]

201. Bernard, E.M.; Fearns, A.; Bussi, C.; Santucci, P.; Peddie, C.J.; Lai, R.J.; Collinson, L.M.; Gutierrez, M.G.M. tuberculosis infection of human iPSC-derived macrophages reveals complex membrane dynamics during xenophagy evasion. J. Cell Sci. 2020, 134, jcs252973.

202. Sanjuan, M.A.; Dillon, C.P.; Tait, S.W.; Moshiach, S.; Dorsey, F.; Connell, S.; Komatsu, M.; Tanaka, K.; Cleveland, J.L.; Withoff, S.; et al. Toll-like receptor signalling in macrophages links the autophagy pathway to phagocytosis. Nature 2007, 450, 1253-1257. [CrossRef]

203. Herb, M.; Gluschko, A.; Schramm, M. LC3-associated phagocytosis initiated by integrin ITGAM-ITGB2/Mac-1 enhances immunity to Listeria monocytogenes. Autophagy 2018, 14, 1462-1464. [CrossRef]

204. Heckmann, B.L.; Boada-Romero, E.; Cunha, L.D.; Magne, J.; Green, D.R. LC3-Associated Phagocytosis and Inflammation. J. Mol. Biol. 2017, 429, 3561-3576. [CrossRef] [PubMed]

205. Martinez, J.; Malireddi, R.K.; Lu, Q.; Cunha, L.D.; Pelletier, S.; Gingras, S.; Orchard, R.; Guan, J.L.; Tan, H.; Peng, J.; et al. Molecular characterization of LC3-associated phagocytosis reveals distinct roles for Rubicon, NOX2 and autophagy proteins. Nat. Cell Biol. 2015, 17, 893-906. [CrossRef]

206. Rolando, M.; Escoll, P.; Buchrieser, C. Legionella pneumophila restrains autophagy by modulating the host's sphingolipid metabolism. Autophagy 2016, 12, 1053-1054. [CrossRef]

207. Kunz, T.C.; Kozjak-Pavlovic, V. Diverse Facets of Sphingolipid Involvement in Bacterial Infections. Front. Cell Dev. Biol. 2019, 7, 203. [CrossRef] [PubMed]

208. Rolando, M.; Escoll, P.; Nora, T.; Botti, J.; Boitez, V.; Bedia, C.; Daniels, C.; Abraham, G.; Stogios, P.J.; Skarina, T.; et al. Legionella pneumophila S1P-lyase targets host sphingolipid metabolism and restrains autophagy. Proc. Natl. Acad. Sci. USA 2016, 113, 1901-1906. [CrossRef] [PubMed]

209. Owen, K.A.; Meyer, C.B.; Bouton, A.H.; Casanova, J.E. Activation of focal adhesion kinase by Salmonella suppresses autophagy via an Akt/mTOR signaling pathway and promotes bacterial survival in macrophages. PLoS Pathog. 2014, 10, e1004159. [CrossRef]

210. Sakuma, C.; Sekizuka, T.; Kuroda, M.; Hanada, K.; Yamaji, T. Identification of SYS1 as a Host Factor Required for Shiga Toxin-Mediated Cytotoxicity in Vero Cells. Int. J. Mol. Sci. 2021, 22, 4936. [CrossRef]

211. Yamaji, T.; Hanamatsu, H.; Sekizuka, T.; Kuroda, M.; Iwasaki, N.; Ohnishi, M.; Furukawa, J.I.; Yahiro, K.; Hanada, K. A CRISPR Screen Using Subtilase Cytotoxin Identifies SLC39A9 as a Glycan-Regulating Factor. iScience 2019, 15, 407-420. [CrossRef] [PubMed]

212. Yamaji, T.; Sekizuka, T.; Tachida, Y.; Sakuma, C.; Morimoto, K.; Kuroda, M.; Hanada, K. A CRISPR Screen Identifies LAPTM4A and TM9SF Proteins as Glycolipid-Regulating Factors. iScience 2019, 11, 409-424. [CrossRef] [PubMed]

213. Capolupo, L.; Khven, I.; Mazzeo, L.; Glousker, G.; Russo, F.; Paz Montoya, J.P.; Ho, S.; Bhandari, D.R.; Bowman, A.P.; Ellis, S.R.; et al. Sphingolipid Control of Fibroblast Heterogeneity Revealed by Single-Cell Lipidomics. bioRxiv 2021. [CrossRef] 